\title{
EKONOMSKO STANJE ZADARSKOG KAPTOLA UOČI PREUSTROJA DALMATINSKIH BISKUPIJA POČETKOM 19. ST.
}

\author{
Zdenko DUNDOVIĆ \\ Teološko-katehetski odjel \\ Sveučilište u Zadru \\ Zadar, Hrvatska
}

\author{
UDK: 338 : 322(497.581.1 Zadar)“18“ \\ DOI: https://dx.doi.org/10.21857/yq32oh4xp9 \\ Izvorni znanstveni rad \\ Prihvaćeno: 20. studenog 2017.
}

\begin{abstract}
U radu se na temelju izvješća zadarskog kapitularnog vikara i arhiđakona Ivana Jurovića iz 1815. godine razmatraju ekonomske prilike i neprilike Zadarskog kaptola uoči preustroja dalmatinskih biskupija za vrijeme druge austrijske uprave u Dalmaciji. Iznose se podatci o prihodima crkvenih institucija i župa Zadarske nadbiskupije u Zadru te o neprilikama s kojima su se susretale, a pomažu boljem razumijevanju crkvenog života na početku 19. stoljeća. Izneseni podatci stavljeni su u korelaciju s izvješćem o materijalnom stanju Zadarskog kaptola radi usporedbe prihoda gradskog i seoskog/ otočnog svećenstva. Uz to, podatci izneseni u radu pridonose usporedbi feudalnog uređenja crkvenog poslovanja i novih privredno-financijskih planova austrijske vlade za buduću crkveno-upravnu cjelinu Zadarske nadbiskupije/metropolije.
\end{abstract}

Ključne riječi: zadarski kaptol, 19. stoljeće, crkvena ekonomija, crkveni posjedi.

\section{UVOD}

Početak 19. stoljeća u Dalmaciji obilježila je smjena prve austrijske uprave i uspostava francuske uprave. Stari zemljišno-posjedovni odnosi iz vremena dugotrajne mletačke vladavine u Dalmaciji nisu se značajnije promijenili ni za prve austrijske, a ni za francuske uprave. Na snazi je i dalje, de facto, bio kolonatski sustav. ${ }^{1}$ Unutar crkvenih reformatorskih pokušaja generalnog providura Vicenza Dandola našao se u to vrijeme u Zadru i zadarski prvostolni kaptol sv. Stošije čiji su se zemljišni posjedi davali u najam prema ustaljenom običajnom pravu. ${ }^{2}$ Reformatorske ideje u vrijeme francuske uprave nisu ozbiljnije zahvatile crkvene institucije u smislu posjedovnih odnosa i sklapanja zakupničkih ugovora $s$ kolonima na zadarskim otocima i primorju, gdje se nalazio najveći dio posjeda Zadarske nadbiskupije početkom 19. stoljeća. ${ }^{3}$ No, ipak su ostavile traga, kako je razvidno iz izvješća zadarskog kapitularnog vikara i arhiđakona Ivana Jurovića od

1 Usp. Šime PERIČIć, Razvitak gospodarstva Zadra i okolice u prošlosti, Zagreb-Zadar, 1999., 139.

2 O stanju Crkve u Dalmaciji pod francuskom upravom vidi rad: Vicko Kapitanović, Hrvatska Crkva pod francuskom vlašću, Croatica Christiana periodica, 18 (1994.), 33, 135 - 136.

3 Usp. Šime PERIčIć, Gospodarske prilike Dalmacije od 1797. do 1848., Split, 1993., 16. 
7. listopada 1815. godine. ${ }^{4}$ Naime, s nastupom druge austrijske uprave nastavio se proces crkvene reorganizacije u Dalmaciji koji je otpočeo još u vrijeme prvog austrijskog upravljanja pokrajinom..$^{5}$ Austrijska vlada potraživala je iscrpna izvješća o personalnom i ekonomskom stanju dalmatinskih biskupija. Već 1815. godine car Franjo I. podrobno je izvješten o tijeku priprema za njihov preustroj. Nakon prikupljenih informacija o stanju mjesnih crkava u pokrajini, car je 1819. godine donio konačnu odluku o preustroju, koja je poslana u Rim, čime je otpočelo razdoblje pregovora carskog dvora sa Svetom Stolicom o tome pitanju. ${ }^{6}$ Ovdje se neće ulaziti u problematiku preustroja crkvene organizacije u Dalmaciji, nego će se na temelju izvješća o stanju Zadarske nadbiskupije, pohranjenih u Državnom arhivu u Zadru i Arhivu Zadarske nadbiskupije, prikazati ekonomsko stanje zadarskog Prvostolnog kaptola na početku 19. stoljeća.

O Stolnom kaptolu sv. Stošije u Zadru u historiografiji postoje pojedine rasprave vezane uglavnom za srednjovjekovlje i javnu djelatnost zadarskog kaptola. U djelima zadarskog povjesničara i kanonika Carla Federica Bianchija Zara Cristiana I. (1877.) i Fasti di Zara (1888.) donosi se kratki povijesni presjek života i djelovanja zadarskog kaptola, njegovih dostojanstvenika i kanonika.

Iako se početak zadarskog Kaptola ne može se sa sigurnošću datirati, općenito se prvi pisani tragovi o kaptolskoj zajednici u Zadru smještaju oko 9. ili početka 10. stoljeća. ${ }^{7} \mathrm{U}$ to vrijeme spominju se kanoničke časti (dignitates) arhiđakon i arhiprezbiter, dok se primicerij, treća kanonička čast, spominje kasnije, u 13. stoljeću. ${ }^{8}$ Turbulentna prošlost i česte izmjene političkih i vojnih vlasti uzrokovale su gubitak stare kaptolske arhivske građe koja bi pomogla u razrješenju pitanja osnutka zadarskog kaptola. ${ }^{9}$ A. Gulin navodi da je teško govoriti o Kaptolu u Zadru prije sredine 9. i početka 10 stoljeća pozivajući se na kronike Šimuna Kožičića Begne, Valerija Pontea, Šimuna Ljubavca, Ivana Tanzlingera Zanottija i Danielea Farlatija koji izrijekom ne spominju Kaptol, već kolegij svećenika i đakona koji su s klericima pomagali biskupu u upravljanju biskupijom. ${ }^{10}$ Međutim, znanstvena rasprava o tom pitanju i dalje je otvorena.

4 Hrvatska - Državni arhiv u Zadru (dalje: HR-DAZD), fond 102, Okružno poglavarstvo u Zadru (dalje: OPZ), kut. 50, br. 4.

5 Slavko Kovačıć, Zadarska nadbiskupija u preustroju dalmatinskih biskupija, Sedamnaest stoljeća Zadarske crkve II. (ur. Livio Marijan), Zadar, 2009., 31 - 34; S. KovAčıć, Ristrutturazione delle circoscrizioni ecclesiastiche in Dalmazia, Istria e Dalmazia nel periodo Asburgico dal 1815 al 1848 (ur. Giorgio Padoan), Ravenna, 1993., 255 - 291.

6 S. Kovačić, Zadarska nadbiskupija u preustroju dalmatinskih biskupija, $34-39$.

Carlo Federico Bianchi, Zara Cristiana I, Zadar, 1877., 167.

Ante Gulin, Srednjovjekovni Katedralni kaptol Svete Stošije u Zadru, Zagreb, 2011., 26.

Znanstvena knjižnica Zadar (dalje: ZKZD), sign. 15878, Ms. 393, fol. $164 \mathrm{v}$.

10 A. Gulin, Srednjovjekovni Katedralni kaptol, 23 - 26. 
Arhiđakonu je pripadala prva čast u kaptolskom zboru, slijedio ga je kanonik arhiprezbiter (natpop), a treću kaptolsku čast obnašao je kanonik primicerij. ${ }^{11}$ Uz njih, kaptolski su zbor sačinjavali kanonici i pripadnici tzv. nižeg klera (clero inferiore), zaduženi prvenstveno za korsku službu u zadarskoj prvostolnoj crkvi i ostale zadaće pridržane kaptolu. Zadaća arhiđakona bila je iznimno važna. On bi sazivao sjednice Kaptola, ravnao kaptolskim vijećem, raspravljao o bitnim stvarima za život i djelovanje Kaptola. Uz to, vodio je brigu o siromasima, upravljao crkvenim posjedima, u slučaju biskupova odsustva upravljao bi i biskupskom menzom, brinuo o odgoju crkvenih kandidata i obavljao ulogu sudca nižeg klera. Arhiprezbiter je bio prvi pomoćnik biskupu za pitanja pastoralne i liturgijske službe. On je aktivno sudjelovao u dužobrižništvu dok ostali kanonici nisu imali tu obvezu (cura animarum), već su obavljali korsku službu u zadarskoj katedrali. ${ }^{12}$ U nadbiskupovoj odsutnosti obavljao bi sve dužnosti u katedrali pridržane nadbiskupu, osim onih koje su iziskivale biskupski red. Primicerij je redovito vodio brigu o izobrazbi đakona, subđakona i minorista te bi, po svojoj službi, ravnao crkvenom glazbom u katedrali. ${ }^{13}$

\section{STANJE I PROBLEMI ZADARSKE CRKVE POČETKOM 19. STOLJEĆA}

Zadarska nadbiskupija početkom 19. stoljeća imala je 27851 duša, od čega je bilo 26928 katolika i 923 pravoslavna vjernika. ${ }^{14}$ Većina prihoda nadbiskupske menze pristizala je $s$ feuda u Sukošanu, u iznosu od 1.600 fiorina godišnje. U vrijeme francuske uprave u Dalmaciji ti su prihodi oduzeti i pripojeni državnoj blagajni (Erario Pubblico). Uz to je nadbiskupska menza posjedovala nekoliko manjih zemljišnih terena u Arbanasima (Borgo Erizzo), opterećenih desetinom, $s$ kojih je, na ime najma, podizala godišnje 108 fiorina. U najmu su bila i zemljišta u Preku (28 fiorina) i Velom Ratu (64 fiorina). Nadbiskupskoj menzi pripadala je kuća nasuprot crkve sv. Frane koja se obično davala u najam za 60 fiorina godišnje, ali je u vrijeme biskupa Scottija pretvorena u hospicij za tri siromašne obitelji. U sklopu nadbiskupskog dvora davala su se u najam dva prostora (botteghe) za

11 O tim crkvenim službama u nas tijekom srednjeg vijeka pisao je: Ivan OstoJIć, Svjetovni kler u staroj Hrvatskoj, Bogoslovska smotra, 38 (3-4), 1969., 410 - 416.

12 HR-AZDN, f. 18, PKZ, Knjiga povlastica Kaptola stolne crkve Sv. Stošije (Liber Privilegiorum Venerabilis Capituli ecclesiae cathedralis S. Anastasiae, martyris), 1399.-1818. (dalje: Liber Privilegiorum), fol. 33; ZKZD, Summario delle Bergamine del Ven. Capitolo della Metropolitana di Zara fatto nell' a. 1757., sign. 16524, Ms. 453, fol. 75.

13 Usp. Ante Gulin, Hrvatski srednjovjekovni kaptoli Dalmacije, Hrvatskog primorja, Kvarnerskih otoka i Istre, Zagreb, 2008., 14 - 15.

14 HR-DAZD, f. 102, OPZ, kut. 50, br. 1. 
200 fiorina godišnje, ali je nadbiskup Scotti i tu primio jednu brojnu siromašnu obitelj. U vlasništvu nadbiskupske menze bile su i neke solane na Pagu, ali su na prijevaru oduzete od mjesnih vlasti, čemu je pogodovala činjenica da su mnogi arhivi u Zadru izgorjeli, a zajedno s njima i vlasnički listovi tih posjeda. ${ }^{15} \mathrm{U}$ vrijeme francuske uprave nadbiskupska menza ostala je bez tih prihoda i bez osmine prihoda crkvene desetine koja je pristizala iz sela tzv. stare stečevine, kao i one s otoka Paga. Crkvena desetina s tih posjeda iznosila je kako slijedi: desetina sela Sukošana 200 fiorina godišnje, desetina sela stare stečevine 1.600 fiorina godišnje i desetina otoka Paga 1.650 fiorina godišnje, što sveukupno čini iznos od 3.450 fiorina. ${ }^{16}$

Tim se novcem održavala nadbiskupska palača, na koju se zbog starosti i nužnosti stalnih obnova godišnje trošilo 480 fiorina. U zadarskoj se katedrali svake godine o Korizmi i Došašću plaćalo propovjednika, a trošak je na godišnjoj razini iznosio 400 fiorina. Nadbiskup je, uz to, plaćao generalnog vikara, kojemu je dodijeljen rezidencijalni beneficij u metropolitanskoj crkvi u visini od 50 fiorina, čemu se iz prihoda nadbiskupske menze pridodavalo 100 fiorina godišnje. Novac se trošio na održavanje seoskih kuća i poboljšanje crkvenih poljoprivrednih zemljišta, a trošak je iznosio 200 fiorina godišnje. Iz prihoda nadbiskupske menze održavala se i zadarska katedrala i troškovi liturgijske službe. ${ }^{17}$

Na temelju Jurovićeva izvješća Okružnom poglavarstvu u Zadru razvidno je da su župe Zadarske nadbiskupije početkom 19. stoljeća raspršene po zaleđu i otocima, a nepristupačnost terena i loši vremenski uvjeti zahtijevali su dugo pješačenje od jednog do drugog mjesta odnosno plovidbu barkom između otočnih župa, zbog čega je svakoj župi proviđen jedan svećenik za vjersku pouku naroda. Ljudi su živjeli u oskudici, nedostajalo je osnovnih živežnih namirnica koje se moralo nabavljati u gradu po visokim cijenama, što je zbog loše prometne povezanosti uzrokovalo i gubitak vremena, a stanovništvo se uglavnom bavilo zemljoradnjom, stočarstvom i ribarstvom. ${ }^{18}$ Sudbinu stanovništva dijelilo je i svećenstvo; slabi prihodi dostajali su tek za uzdržavanje tijekom nekoliko mjeseci u godini, ${ }^{19}$ a uslijed oskudice svećenstvo se bavilo zemljoradnjom i ribarstvom, što se izričito protivilo biskupskim odredbama. ${ }^{20}$

15 HR-DAZD, f. 102, OPZ, kut. 50, br. 3.

16 HR-DAZD, f. 102, OPZ, kut. 50, br. 4.

17 HR-DAZD, f. 102, OPZ, kut. 50, br. 5.

18 Usp. Š. PERIČıć, Gospodarske prilike Dalmacije, 144.

19 HR-DAZD, f. 102, OPZ, kut. 50, br. 12.

20 Usp. Grozdana Franov-ŽIvković, Glagoljske moralno-kazuističke odredbe ninskih biskupa, 17. i 18. st., Radovi Zavoda za povijesne znanosti HAZU u Zadru, 57 (2015.), 189. 
Jurović je naglasio da izvangradske župe poslužuje isključivo glagoljaško svećenstvo (Prete del Rito Illirico) te je na temelju austrijskog Priručnika o crkvenom zakonu (Enchiridion Iuris Ecclesiastici Austriaci) ${ }^{21}$ zatražio da im se dodijeli prihod jednak onomu koji su imali austrijski kapelani u visini od 300 - 350 fiorina. ${ }^{22}$ Njihovi predviđeni godišnji prihodi prikazuju se tablično radi usporedbe primitaka gradskog i seoskog/otočnog svećenstva početkom 19. stoljeća (Tablica 1). Prihodi župnika sastojali su se od dijela crkvene desetine, mršavih i neredovitih doprinosa vjernika, $s$ obzirom na njihovo ekonomsko stanje, i štolarine. ${ }^{23}$ Razvidna je neujednačenost prihoda pojedinih seoskih i otočnih župa početkom 19. stoljeća. Uostalom, loš materijalni status svećenstva na selima bio je jedan od razloga crkvenom preustroju u Dalmaciji čiji je prijedlog austrijska diplomacija 1819. godine iznijela papi Piju VII. (1800. - 1823.). ${ }^{24}$ Ipak, zamjetno je da su neke otočne župe, iako brojčano slabije u odnosu na kopnene imale izdašnije prihode tj. bile profitabilnije. Primjerice, Župa Rava imala je tada 200, a Župa Bibinje 304 stanovnika. ${ }^{25} \mathrm{~S}$ obzirom na demografski odnos dvaju naznačenih mjesta, godišnji su župni prihodi bili obrnuto proporcionalni. Dijelom se to može pripisati činjenici da je na otocima bilo manje obradivih površina, što je pridonosilo i većoj marljivosti stanovništva, a otočani su nerijetko uzimali u zakup i zemljišta na zadarskoj terafermi. ${ }^{26}$

TABLICA 1. Popis župa, župnika i prihoda 1818. godine.

\begin{tabular}{|l|l|c|l|}
\hline \multicolumn{1}{|c|}{ Župa } & \multicolumn{1}{c|}{ Župnik } & Prihodi u fiorinima & \multicolumn{1}{c|}{ Bilješke } \\
\hline Olib & Stjepan Piculić & 360 & 2 kapelana \\
\hline Silba & Nediljko Zupičić & 296 & 1 kapelan \\
\hline Premuda & Ivan Marija Jadrošić & 224 & \\
\hline Ist & Petar Smoljan & 113 & \\
\hline Molat & Šime Abelić & 125 & \\
\hline
\end{tabular}

${ }^{21}$ Priručnik je sastavio austrijski crkveni i civilni pravnik Georg Rechberger, a prvi je put objavljen u Linzu 1807. godine. O tome više kod: Marko TROGrLIĆ, Preustroj župa u Zadarskoj nadbiskupiji (1829.-1849), Sedamnaest stoljeća Zadarske crkve II. (ur. Livio Marijan), Zadar, 2009., 82.

22 HR-DAZD, f. 102, OPZ, kut. 50, br. 12.

23 Štolarina se odnosi na novčane pristojbe koje su se župnicima podavale prigodom krštenja, vjenčanja i sahrana.

24 Usp. Stjepan Ćosıć, Crkveni preustroj i državna uprava u Dalmaciji 1828. godine, Sedamnaest stoljeća Zadarske crkve II. (ur. Livio Marijan), Zadar, 2009., 70.

25 HR-DAZD, f. 102, OPZ, kut. 51, br. 20470/3321, fol. 10 - 11.

26 Usp. Grozdana Franov-Žıvković, Glagoljaš don Ive Vlahić iz Sutomišćice (o. 1733.-25. VII. 1803.), Radovi Zavoda za povijesne znanosti HAZU u Zadru, 54 (2012.), 161. 
Zdenko Dundović: Ekonomsko stanje zadarskog kaptola uoči preustroja...

\begin{tabular}{|c|c|c|c|}
\hline Župa & Župnik & Prihodi u fiorinima & Bilješke \\
\hline Brgulje & Šime Lovretić & 87 & \\
\hline Sestrunj & Petar Švorinić & 84 & \\
\hline Božava & Šime Uglešić & 391 & 2 kapelana \\
\hline Dragove & Ante Vidušić & 101 & \\
\hline Brbinj & Ante Rančić & 121 & \\
\hline Savar & Ivan Šarunić & 105 & \\
\hline Luka & Mihovil Bubičin & 86 & \\
\hline Žman & Petar Zabrulić & 70 & \\
\hline Sali & Ivan Bobić & 191 & 1 kapelan \\
\hline Rava & Ivan Šatalić & 101 & \\
\hline Iž Veli & vacante & 108 & \\
\hline Iž Mali & Mihovil Gaćina & 82 & \\
\hline Ugljan & Šime Milin & 166 & 1 kapelan \\
\hline Lukoran & Grgur Goban & 118 & \\
\hline Sutomišćica & Ivan Levačić & 178 & 1 kapelan \\
\hline Preko & Ivan Košta & 173 & \\
\hline Kali & Ivan Dražić & 102 & \\
\hline Kukljica & Lovre Pestić & 149 & \\
\hline Ždrelac & Ante Brajković & 85 & \\
\hline Banj & Frane Franić & 140 & \\
\hline Dobropoljana & Ante Kulonja & 80 & \\
\hline Neviđane & Božo Kučina & 89 & \\
\hline Pašman & Jure Burić & 149 & \\
\hline Vrgada & Martin Mičić & 163 & \\
\hline Arbanasi & Šime Rakar & 185 & \\
\hline Bibinje & Ivan Španić & 75 & \\
\hline Sukošan & Šime Čalović & 171 & \\
\hline Turanj & Šime Bolić & 84 & \\
\hline Sv. Filipjakov & Mate Rudić & 131 & \\
\hline Biograd & Krševan Lukačić & 232 & \\
\hline Pakoštane & Ivan Vulin & 200 & \\
\hline Vrana & Mate Stazić & 180 & \\
\hline Radošinovci & Petar Torić & 134 & \\
\hline Pristeg & Jure Torić & 228 & \\
\hline Škabrnja & Stipe Torić & 238 & \\
\hline Tinj & Stipe Kaštelanić & 130 & \\
\hline
\end{tabular}




\begin{tabular}{|l|l|c|c|}
\hline \multicolumn{1}{|c|}{ Župa } & \multicolumn{1}{c|}{ Župnik } & Prihodi u fiorinima & Bilješke \\
\hline Gorica & Mate Bačinić & 196 & \\
\hline Galovac & vacante & 183 & \\
\hline Zemunik & Mihovil Šarić & 330 & \\
\hline Crno & Toma Škvorlić & 100 & \\
\hline Murvica & Josip Marcelić & 164 & \\
\hline Grusi & Bartol Pavić & 181 & \\
\hline Bokanjac & Martin Pestić & 138 & \\
\hline Kožino & Mate Pavić & 137 & \\
\hline Petrčane & Blaž Martinović & 136 & \\
\hline Diklo & Ante Garković & 176 & \\
\hline Ljubač & Miho Dunatov & 141 & \\
\hline Radovin & Jakov Dundović & 193 & \\
\hline Gorica (Pag) & Jure Kožul & 54 & \\
\hline Dinjiška & Nediljko Lovrinčić & 113 & \\
\hline Vlašić & Šime Španić & 112 & \\
\hline Povljana & Petar Gojdanić & 145 & \\
\hline Kolan & Jure Pavlović & 113 & \\
\hline Polača & Ivan Stagličić & 228 & \\
\hline Tkon & Bartol Mađerić & 206 & \\
\hline Izvor: & & & \\
\hline
\end{tabular}

(Izvor: HR-DAZD-102, Okružno poglavarstvo u Zadru, kut. 50.)

Šime Peričić navodi kako je dekretom iz 1810. godine desetina bila proglašena javnim porezom, a "nepromijenjeno stanje je ostalo na crkvenim dobrima“. ${ }^{27}$ Ta tvrdnja nije u potpunosti točna. Naime, iz izvješća arhiđakona Jurovića razvidno je da su se dekretom 1810 . godine u Ljubljani dokinule crkvene desetine pripadajuće biskupima, kaptolima i crkovinarstvima. Zauzvrat je francuska uprava trebala obeštetiti te crkvene institucije iz državne blagajne, što je ona i činila, ali je pritom umanjivala određene kvote, što je crkvenu desetinu u Zadru umanjilo za 3.000 franaka na godišnjoj razini. ${ }^{28} \mathrm{U}$ to je vrijeme Zadarski kaptol sačinjavalo 29 pojedinaca, bez onih iz kolegijalne crkve sv. Šimuna, koji su dijelili kaptolske prihode. ${ }^{29}$

27 Š. PERIČIĆ, Gospodarske prilike Dalmacije, 16, bilj. 48.

28 HR-DAZD, f. 102, OPZ, kut. 50, br. 4.

29 Popis i opis članova kaptolskog zbora s početka 19. stoljeća donosi: Josip CELIĆ, Svjetovno svećenstvo i redovništvo u Zadru po službenom iskazu iz 1811. godine, Radovi Zavoda za povijesne znanosti HAZU u Zadru, 57 (2015.), 220 - 229. 


\section{PODJELA PRIHODA MEĐU NADARBENICIMA ZADARSKOG KAPTOLA}

Temeljna prava nadarbenika Zadarskog kaptola okvirno obuhvaćaju pravo na službenu dobit i počasna prava. Pravo na službenu dobit podrazumijeva prebendu (prihod od nadarbeničke službe), ${ }^{30}$ dnevnu distribuciju za službu u koru te neke neredovite prihode izvanrednih pjevanih misa, pogrebnih obreda i sl. Prihodi su se dijelili prema prastarom običajniku Zadarskog kaptola. Osnovicu za podjelu prihoda među zadarskim kapitularcima činio je trideseti dio sveukupnog iznosa. Pritom je arhiđakonu pripadao dvostruki kanonički dio, ostalim dostojanstvima i kanonicima jedan dio, mansionarima i septemanarima polovica kanoničkog dijela, đakonima četvrtina, subđakonima osmina, a akolitima šesnaesti dio kanoničkog dijela per capita. Počasna prava nadarbenika podrazumijevaju uzvišenije mjesto u korskim sjedalima (superiore), određeno prema važnosti službe i starosti kanonika, i pravo na nošenje almuzije (zanfarde), ${ }^{31}$ koju su kanonici nosili za vrijeme crkvenih svečanosti i procesija. Šestorica katedralnih mansionara imali su također pravo nositi zanfardu, ali bez dodatnih uresa (code pendenti) i sjedili su u prvim sjedalima u koru (inferiore), a za njima su slijedili septemanari i ostali pripadnici nižeg klera.

Kaptol je u vrijeme mletačke uprave imao pravo na podizanje desetine $s$ otoka, primorja i 35 sela u zadarskom zaleđu (vecchio e nuovo acquisto). Tada su kanonici uprihodovali po 30 talara, što je bio vrlo izdašan prihod u vremenima scarsissimi di moneta. Zbog mletačko-osmanskih ratova nestala su sela u zaleđu i s njima desetina pa je Kaptol osiromašio te je mletačka vlada dukalom od 19. rujna 1739. godine u zamjenu za desetinu triju sela (Zemunik, Račice i Sveta Sofija $)^{32}$ iz državne blagajne dodijelila kanonicima godišnju pripomoć u iznosu od 50 cekina.

30 Bitno je razlikovati da nadarbina i prebenda nisu istoznačnice. Crkvena je nadarbina (beneficium) vlasniku koji ju posjeduje izvor prihoda (praebenda), a uvijek je vezana uz neku crkvenu službu (officium). Jadranka Neralić, Put do crkvene nadarbine, Split, 2007., 101.

31 Zanfarda ili almutia (kratki ogrtač, preteča mocete) liturgijski je parament koji su rabili kanonici u koru, a redovito se nosio preko lijevog ramena. Potječe iz nordijskih zemalja i najčešće je bio izrađen od krzna. Osim liturgijske uporabe, imao je i vrlo praktičnu svrhu - utopliti svoga vlasnika za vrijeme molitve časoslova u hladnoj katedrali, osobito za zimskih mjeseci. Usp. I. Ostojıć, Metropolitanski kaptol u Splitu, Zagreb, 1975., 129.

32 Selo Račice nalazilo se na području današnjeg Galovca. Usp. Nikola JA Kšıć, Vladarska zadužbina sv. Bartula u srednjovjekovnom selu Tršci, Radovi Zavoda za povijesne znanosti HAZU u Zadru, 42 (2000.), 18 - 19. Selo Sv. Sofija nalazilo se na području današnje istočne Murvice. U predtursko doba na mjestu današnjeg Smokovića nalazilo se selo Opatice Vas ili Opatice Selo s crkvom sv. Sofije. Marko Rimac, Goran Mladineo, Zadarsko okružje na mletačkom katastru iz 1709. godine. Drugi dio. Srednji kotar, Zadar, 2011., 98. 
Dnevna distribucija označavala je dodatne prihode za nazočnost u koru (punti lucrativi). O punktiranju nazočnosti u koru brigu su vodili kaptolski prokuratori. ${ }^{33}$ Visina iznosa dnevne distribucije nije bila fiksna, ovisila je o nazočnosti nadarbenika u koru, kojima bi se za kaznu oduzimao dio prihoda razmjerno vremenu odsutnosti iz korske službe, a nazočnim kanonicima povećavao se udio dnevnih distribucija na teret onih odsutnih. Za podmiru dnevnih distribucija izdvajao se mali iznos (750 lira) iz mletačke pripomoći (50 cekina) i nekih manjih prihoda. Dnevne distribucije imale su za svrhu potaknuti revnost kod nadarbenika u korskoj službi te je kanonik, ako je bio redovito nazočan u koru, mogao, uz prebendu, namrijeti još 24 fiorina prihoda godišnje u svoju korist. $S$ obzirom da početkom 19. stoljeća Kaptol nije više primao pomoć (50 cekina), umanjio se i iznos dnevnih distribucija. Kanonici su, uz to, godišnje dobivali od sprovoda i pjevanih misa $5-6$ libri svijeća, ${ }^{34}$ a u novcu 12 fiorina. Uz to, prihodi za dnevne distribucije kanonicima su pristizali od pojedinih najmova i zakupa zemlje i nekretnina. Primjerice, nadarbina sv. Petra u Diklu donosila je oko 600 lira godišnje, za dnevne distribucije, dok je sveukupni iznos prihoda od najma zemljišta iznosio 1.251 liru. Monte Ferreo, kapele i dr. donosili su 960 lira. Od tih prihoda (i drugih) namirivale su pjevane mise i tihe (737). Zbog gubitka desetine za vrijeme francuske uprave ostali su kanonici bez redovitih prihoda te su mnoge službe obavljali gratis, što je konačno značilo da je svaki kanonik živio od 25 fiorina tromjesečno, odnosno 100 fiorina na godišnjoj razini. ${ }^{35}$ Sveukupni prihodi posjeda Zadarskog kaptola i drugi izvori prihoda, osim onih koji su bili vezani uz osobni beneficij pojedinog kapitularca, činili su kapitularnu masu (massa communis), a njihova podjela vršila se prema spomenutom običajnom pravu. ${ }^{36}$

\section{PODRIJETLO ZEMLJIŠNIH POSJEDA ZADARSKOG KAPTOLA}

Dobra zadarskog Kaptola sv. Stošije početkom 19. stoljeća mogu se okvirno podijeliti na nekretnine davane u zakup (livello) ili najam (affitto $)^{37}$ unutar samih

33 Usp. I. OstojIć, Metropolitanski kaptol u Splitu, 126 - 127.

34 O vrijednosti mletačke mjere za težinu - libra vidi kod: Marija ZANinović-RumorA, Zadarske i šibenske mjere za težinu kroz stoljeća, Radovi Zavoda za povijesne znanosti HAZU u Zadru, 40 (1998.), $161-164$.

35 HR-DAZD, f. 102, OPZ, kut. 50, br. 4.

36 Usp. I. OstojIć, Metropolitanski kaptol u Splitu, 38.

37 Potrebno je naglasiti da je pojam najma (affitto) u to vrijeme bio identičan današnjem pojmu, dok je zakup (livello) daleko složeniji, raznovrsniji i dugotrajniji oblik ugovornog odnosa koji u historiografiji nije do kraja razjašnjen što treba uzeti u obzir kod čitanja teksta. Usp. Dubravka KolIć, Inventar fonda obitelji Lantana, Radovi Zavoda za povijesne znanosti HAZU u Zadru, sv. 49, 2007., 365. 
gradskih zidina i zemljišne terene van gradskih zidina, većinom uz kapele u blizini grada, na području Monte Ferrea, priobalja i zadarskih otoka. ${ }^{38}$ Područje Monte Ferreo u prostornom i pravnom smislu tijekom 19. stoljeća rastezalo se od današnjeg graničnog područja Bokanjca i Bilog Briga pa sve do granice između Turnja i Sv. Filipa i Jakova.

Kaptol je kroz povijest svoja dobra najčešće stjecao darovnicama i oporučnim pismima vladara, građana i crkvenih službenika. Od njegove obnove u vrijeme nadbiskupa Petra Matafara do pada Mletačke Republike mnogi zadarski građani i crkveni službenici oporučno su ostavljali novac, nekretnine i zemljišta na dar Prvostolnom kaptolu sv. Stošije, a znatan dio tih posjeda bio je u vlasništvu kaptola i početkom 19. stoljeća. ${ }^{39}$ Saznaje se da je prve zemljišne terene na Monte Ferreu obnovljenom zadarskom Kaptolu oporučno ostavio primicerij Krševan (Grisogono) de Cigalis, ${ }^{40}$ koje je 26. listopada 1366. godine Kaptol podijelio $s$ Krševanovim nećakom Damjanom. ${ }^{41}$ Zemljišta na prostoru Monte Ferrea najvećim su dijelom darovana zadarskom Kaptolu tijekom 14. i 15. stoljeća, kako je razvidno iz prijepisa oporučnih pisama u kaptolskoj knjizi dobara. ${ }^{42}$ Zauzvrat, u oporukama su darovatelji tražili da kanonici zadarskog Kaptola mole za njihove duše točno precizirajući koliko misa, vespera i aniverzarija (godišnjica smrti) Kaptol treba slaviti na ime ostavštine. ${ }^{43}$ Početkom 19. stoljeća Zadarski kaptol je na ime oporuka, legata i darovnih ostavština slavio u katedrali 737 misa godišnje (Tab. 2.)

TABLICA 2. Misne obveze Zadarskog kaptola za dobročinitelje početkom 19. stoljeća.

\begin{tabular}{|l|l|r|}
\hline Misna nakana & Vrsta mise & \multicolumn{1}{|l|}{ Broj misa } \\
\hline za pok. Ferra & tiha misa & 88 \\
\hline za pok. kanonika Lukšu & tiha misa & 60 \\
\hline
\end{tabular}

38 ZKZD, sign. 22609, Ms. 579, 255 - 256.

39 Opsežnu dokumentaciju o darovateljima zemalja prikupio je zadarski Kaptol 1784. godine u svežanj pod naslovom Per le Terre sotto 'l Monte Ferreo, E altre nei contorni della Città di Zara Di raggione del Ven(erabi)le Capitolo. Documenti raccolti l'Anno 1784. Hrvatska - Arhiv Zadarske nadbiskupije (HR-AZDN), fond 18, Prvostolni kaptol u Zadru (dalje: PKZ), Razni spisi, svež. 102.

40 O njemu više kod: A. Gulın, Srednovjekovni katedralni kaptol, 48 - 50.

41 HR-AZDN, f. 18, PKZ, Razni spisi, svež. 102. fol. 1 - 4.

42 HR-AZDN, f. 18, PKZ, Dobra i nadarbine Zadarskoga kaptola (Bonorum beneficiorumque Venerabilis Capituli Jadrensis documenta), 1427.-1851. (dalje: Bonorum beneficiorumque), kut. 15/64, svež. 5, fol. 232 - 267. Usp. ZKZD, sign. 16524, Ms. 453, fol. 2 - 3.

43 Broj misa u oporukama nerijetko je sadržavao i određenu simboliku. Misa ima osobitu ljekovitost za umrljanu dušu pokojnika. Usp. Zdenka JANEKović Römer, Na razmeđi ovog i onog svijeta. Prožimanje pojavnog i transcedentnog u dubrovačkim oporukama kasnoga srednjega vijeka, Otium, 2 (1994.), 3 - 15. 


\begin{tabular}{|l|l|r|}
\hline za pok. kanonika Mazarachija & tiha misa & 52 \\
\hline za pok. kanonika Mladošića & tiha misa & 36 \\
\hline za pok. svećenika De Rubeisa & tiha misa & 52 \\
\hline za nepoznate dobročinitelje & tiha misa & 178 \\
\hline za pok. Kevrića & tiha misa & 80 \\
\hline za pok. Cipica & tiha misa & 57 \\
\hline za pok. Capelettija & tiha misa & 5 \\
\hline legat Barbaro & tiha misa & 21 \\
\hline za pok. Ivana Castellija & tiha misa & 27 \\
\hline za pok. Tikulina & tiha misa & 7 \\
\hline za pok. Formajevića & tiha misa & 7 \\
\hline za pok. Bachija & tiha misa & 7 \\
\hline za dobročinitelje koji su Kaptolu ostavili kuće i trgovine & tiha misa & 52 \\
\hline za razne dobročinitelje & pjevana misa & 14 \\
\hline za pok. Hilarija Guerinija & pjevana misa & 4 \\
\hline
\end{tabular}

(Izvor: HR-DAZD-102, Okružno poglavarstvo u Zadru, kut. 50.)

Kaptol je slobodno raspolagao tim nekretninama, najčešće ih je davao u zakup (livello) ili najam (affitto), ali ih je nerijetko prodavao ako nisu donosile dostatan prihod za održavanje nadarbine. Utrženim novcem kupovao bi kvalitetnije terene ili nekretnine čijim bi se daljnjim zakupom ili najmom mogla nesmetano izvršiti volja darovatelja ili oporučitelja. Odlukom Tridentskog sabora crkvene se nadarbine nisu smjele davati u najam na više od tri godine. Ta je činjenica tijekom 18. stoljeća utjecala na materijalno stanje zadarskog Kaptola zbog neisplativosti kratkoročnog najma pa je bilo teško naći zainteresirane najmitelje. $\mathrm{K}$ tomu, kaptolske su zemlje zbog ratova bile zapuštene, a vinogradi ostarjeli, što je dodatno otežavalo davanje u najam jer je najmiteljima bilo teško uživati plodove vlastitog rada u tako kratkom roku na prilično zahtjevnom zemljištu. ${ }^{44}$

Kada je riječ o nekretninama (kuće, pekare i trgovine), njih je Kaptol mogao iznajmljivati na dulje vrijeme. Važno je naglasiti da je odobrenje tih najmova davala Sveta Stolica. ${ }^{45}$ Štoviše, kada prihodi nekih nekretnina ne bi pokrivali troškove legata i oporučnih misnih obveza, Kaptol je morao od Rima

44 O stanju svojih zemljišta Kaptol kazuje: Cum ex multo tempore obseruaruit Ven(erabile) Cap(itu) lum quod de die in diem semper de malo in peius praecipitent Bona Cap(ito)laria, quae possidet tam in Terra Ferma, prope Ciuitatem, quam per Scopula huius Dioecesis. HR-AZDN-18, Prvostolni kaptol u Zadru, Kaptolske sjednice, Liber Partium 32/III (dalje: Liber Partium 32/III), kut. 7, fol. $2 \mathrm{v}$.

45 HR-AZDN, f.18, PKZ, Bonorum beneficiorumque, fol. 97 - 98. 
zatražiti redukciju tih obveza ili dopuštenje o sklapanju povoljnijeg ugovora. ${ }^{46}$ Kuće i ostale nekretnine održavali bi i obnavljali ili sami najmitelji ili Kaptol kao vlasnik nekretnine, ovisno o vrsti sklopljenog ugovora, redovito na bazi emfiteuze. ${ }^{47}$ Nerijetko je promjena vrijednosti mletačke monete odredivala i promjenu visine iznosa najma nekretnina, što je uzrokovalo nesporazume i odbijanje plaćanja najamnine, kao i raskid ugovora između najmitelja i Kaptola. ${ }^{48}$ Promjene monetarne vrijednosti odredivale su i modus sklapanja ugovora o najmu nekretnina. ${ }^{49}$

Sami kaptolski dostojanstvenici, kanonici i zadarski kler oporučno su ostavljali svoja dobra (uglavnom kuće i zemljišta) u vlasništvo zadarskom Kaptolu, uvijek uz određenu obvezu svetih misa i molitava za svoje duše i duše svojih rođaka. Ponekad su oporučna pisma bila uzrokom prijepora između Kaptola, pojedinaca i institucija državne i crkvene vlasti.

Na temelju zahtjeva mletačkih vlasti s početka 18. stoljeća zadarski je Kaptol bio dužan popisati i prezentirati sva svoja dobra i nadarbine. Kako je razvidno iz kaptolske knjige dobara Bonorum Beneficiorumque Venerabili Jadrae Capituli Documenta i knjige kaptolskih privilegija Liber Privilegiorum, zadarski su kanonici tijekom 17. i 18. stoljeća nekoliko puta prepisivali i bilježili terene u vlasništvu Kaptola, njihov položaj, granice i veličinu, kao i materijalno stanje zemljišta. Pritom su se služili starim kartama i dokumentima kaptolskog arhiva. Sve je navedene terene u vlasništvu Kaptola s područja Monte Ferrea, kao i terene vezane uz pojedine kapele van gradskih zidina, zapisao kanonik Ivan Tanzlingher Zanotti, s osobitom pomnjom, u knjigu Bonorum Beneficiorumque iz originalne, autentične knjige, s točnim geometrijskim mjerama i svime što dokazuje autentičnost iznesenih podataka. ${ }^{50}$ Zahvaljujući tim popisima i kartama moguće je relativno vjerno utvrditi broj i položaj nekretnina u vlasništvu zadarskog Kaptola i početkom 19. stoljeća.

Zadarski Kaptol sv. Stošije posjedovao je tijekom 18. stoljeća nekretnine kako slijedi: oko 30 gonjaja zemlje na lokalitetima Monte Ferreo i Paprat koje je Kaptolu oporučno ostavio arhiđakon Luka, ${ }^{51} \mathrm{~s}$ obvezom misnog slavlja na godišnjicu smrti; više terena na istoj lokaciji (Monte Ferreo i Paprat), kupljenih u dva navrata novcem koji je Kaptolu ostavila pok. Elizabeta kći hrvatskoga

46 HR-AZDN, f. 18, PKZ, Bonorum Beneficiorumque, fol. 475.

47 HR-AZDN, f. 18, PKZ, Liber Partium 32/III, fol. 10v.

48 HR-AZDN, f. 18, PKZ, Liber Partium 32/III, fol. $51 \mathrm{v}$.

49 HR-AZDN, f. 18, PKZ, Liber Partium 32/III, fol. 52v - 53r.

50 HR-AZDN, f. 18, PKZ, Bonorum Beneficiorumque, fol. 678.

51 Oporuka od 17. svibnja 1417. godine i kodicil arhiđakona Luke zapisani su u kaptolskim spisima. HR-AZDN, f. 18, PKZ, Razni spisi, svež. 102., fol. 27 - 32. 
bana Pavla (Paolo Bano de Croatia), ${ }^{52}$ s obvezom slavlja svetih misa na oltaru sv. Kristofora u crkvi sv. Stošije, koja je kasnije prebačena na oltar sv. Uršule i reducirana na slavlje dnevne mise zajedno s obvezom za terene na Stublju $\left(\right.$ Stubal $^{53}$; 16 gonjaja zemlje u blizini crkve sv. Marka zvanog Luk (all' Arco), koju je oporučno ostavio svećenik Pavao de Santis, ${ }^{54}$ s obvezom jedne mise tjedno i godišnjice; komad terena kod crkve sv. Ivana pod nazivom Ograda, ${ }^{55}$ koji je oporučno ostavio svećenik Santo de Santis stariji, s obvezom jedne mise tjedno; pekarnica (il forno) i kuća kod crkve sv. Vida iznad sv. Katarine, koju je oporučno ostavio kanonik Ivan Manjurić, $s$ obvezom jedne mise tjedno i godišnjice. ${ }^{56}$ Zadarski je Kaptol 1701. godine tu kuću dao u zakup kanoniku Bernardu Piazzi i Luciji, ženi pok. Marka Dušmanovića. Iz dokumenta ugovora doznaje se da je kuća bila smještena u ulici sv. Vida. Ugovor je sklopljen u emfiteutskoj formi in perpetuo s godišnjom daćom u visini 15 dukata koje su zakupnici bili dužni isplatiti zadarskom Kaptolu. ${ }^{57}$

Kaptol je 1656. godine kupio u Zadru kuću zadarskog trgovca Josipa Tomadellija, pok. Vinka, smještenu u ulici sv. Marije, u blizini crkve sv. Donata, nasuprot poljane sv. Luke za 500 dukata. ${ }^{58}$ Kaptol je posjedovao kuću prislonjenu na providurovu palaču, čije vlasništvo je dijelio s Horacijem Ponteom, smještenu kod mosta, nasuprot javnih zgrada na vratima koja vode prema kopnu. ${ }^{59}$

U vlasništvu je zadarskog Kaptola tijekom 18. stoljeća i zakup (livello) kuće kanonika Ivana Rada, čija je oporuka zapisana u knjizi kaptolskih dobara. ${ }^{60}$

52 Krivo je upisano u dokumentu da se radi o kćeri hrvatskog bana Pavla, s obzirom da ban Pavao nije imao kćeri nego pet sinova. Izgledno je, međutim, da je i ban Pavao Šubić bio darovatelj zadarskih crkva i samostana, kako to donosi Nikola Ja Kš Ić, Kult sv. Petra u kasnoantičkom i srednjovjekovnom Zadru, Scripta Branimiro Gabričević dicata (Zbornik u čast Branimira Gabričevića) (ur. Josip Dukić, Ante Milošević, Željko Rapanić), Trilj, 2010., 336.

53 Radi se o lokalitetu na području današnjeg Dračevca Zadarskog. Izvorno riječ stubalj označava studenac, a i danas se na tom lokalitetu nalazi izvor vode zajedno $s$ bunarom koji mještani koriste za natapanje okolnih polja i vinograda. Usp. Vladimir SKRAČIĆ - Ante JURIĆ, Krški leksik zadarske regije, Geoadria, 9 (2), 2004., 167.

54 Tekst oporuke prepisan je u kaptolsku knjigu dobara. HR-AZDN, f. 18, PKZ, Bonorum Beneficiorumque, fol. 119 - 122.

55 Teren je koncem 17. stoljeća bio veličine oko 5 gonjaja, dijelom obradiv, a dijelom pod vinogradom na području Smiljevca (... a Smiglievaz luoco in Terra ferma). HR-AZDN, f. 18, PKZ, Razni spisi, svež. 102, fol. 69.

56 Oporuka don Ivana Manjurića nalazi se u kaptolskoj knjizi Bonorum Beneficiorumque, fol. 179 180. Usp. ZKZD, sign. 16524, Ms. 453, fol. $16-17$.

57 HR-AZDN, f. 18, PKZ, Bonorum Beneficiorumque, fol. $642-643$.

58 HR-AZDN, f. 18, PKZ, Bonorum Beneficiorumque, fol. 378 - 386; ZKZD, sign. 16524, Ms. 453, fol. $26-27$.

59 HR-AZDN, f. 18, PKZ, Liber Partium 32/III, fol. 3r - 3v.

60 HR-AZDN, f. 18, PKZ, Bonorum Beneficiorumque, fol. 143. 
Kuća koju je oporučno ostavio kanonik Ivan Rado nalazila se u blizini crkve sv. Donata, imala je dvorište, vrt i jednu trgovinu, a zakup su baštinici bili dužni plaćati zadarskom Kaptolu ${ }^{61} \mathrm{~s}$ obzirom da je bila u kaptolskome vlasništvu i iznajmljena emfiteutskim ugovorom kanoniku Ivanu Radu. ${ }^{62}$ Ugovor o zakupu kuće obnavljao se svakih pet godina. Kako je razvidno iz kaptolskih dokumenata, baštinici kanonika Rada često su kasnili s isplatom zakupa pa se Kaptol s njima sporio. ${ }^{63}$ Kasnije je tu kuću oporučno ostavio kanonik Petar Kriminalić, s obvezom misnog slavlja na godišnjicu smrti.

Kaptol je polagao pravo na zakup kuće Loccadello, koju je oporučno ostavio kanonik Bartolomej Bičanić, ${ }^{64} \mathrm{~s}$ obvezom misnog slavlja na godišnjicu smrti; pekarnicu na poljani sv. Luke, koju je oporučno ostavio svećenik Tanus, s obvezom pet tihih misa i godišnjice; zakup jedne kuće koju je oporučno ostavio pok. Mašurinka, s obvezom misnog slavlja na godišnjicu smrti; Kaptolu pripadaju tereni u Gaženici, zajedno s naznačenom kućom primicerija Colone, koju je oporučno ostavio kanonik Mladošić, s obvezom svete mise svakog drugog tjedna na oltaru sv. Martina u zadarskoj katedrali; tereni na Žankovcu i u Banju, ${ }^{65}$ s kućom u kojoj je tada stanovao kapetan Antun Marinoni, koje je Kaptolu oporučno ostavio klerik Petar de Rubeis 1531. godine,${ }^{66}$ s obvezom jedne mise tjedno na oltaru Presvetog Sakramenta; tereni u Lukoranu, zajedno s kućom, i zakupom dviju kuća u Zadru, koje je Kaptolu oporučno ostavio kanonik Ivan Barbić, s obvezom godišnjice i jedne mise tjedno u njegovoj kapeli u Lukoranu. ${ }^{67}$ Kanonik Ivan Barbić oporučno je 1564. godine ostavio Kaptolu sva svoja dobra, a zapisao ih u podužoj knjižici (in mio libro lungo), što govori o brojnosti terena u njegovu posjedu. ${ }^{68} \mathrm{Na}$ temelju Barbićeve oporuke Kaptol je bio dužan jednom godišnje isplatiti lukoranskom župniku iznos od 12 lira te mu na blagdan Rođenja Blažene Djevice Marije 8. rujna dati jednu torzu (velika voštana svijeća) težine 12 unci i dvije svijeće težine po 4 unce. Lukoranski župnik dužan je zauzvrat reći jednu tihu misu tjedno i moliti za Barbićevu dušu u kapeli koju je kanonik

61 HR-AZDN, f. 18, PKZ, Bonorum Beneficiorumque, fol. 142.

62 HR-AZDN, f. 18, PKZ, Bonorum Beneficiorumque, fol. 146 - 147.

63 HR-AZDN, f. 18, PKZ, Bonorum Beneficiorumque, fol. 149.

64 Kanonik Bartolomej Bičanić oporučno je Kaptolu ostavio 7. rujna 1538. godine una domus de muro solevata, cuppis cooperta, posita super terreno Hospitalis Sancti Martini Iadrae in confinio Sancti Viti, siue Sanctae Catherinae. HR-AZDN, f. 18, PKZ, Bonorom Beneficiorumque, fol. 93.

65 ZKZD, sign. 16524, Ms. 453, fol. 10 - 11; fol. 15; fol. $19-20$.

66 Oporuka Petra de Rubeisa u cijelosti se donosi u knjizi HR-AZDN, f. 18, PKZ, Bonorum Beneficiorumque, fol. 318 - 322 .

67 HR-AZDN, f. 18, PKZ, Bonorum Beneficiorumque, fol. 73.

68 Oporuka Ivana Barbića od 17. rujna 1564. godine. HR-AZDN, f. 18, PKZ, Bonorum Beneficiorumque, fol. 72; HR-AZDN, f. 18, PKZ, Razni spisi, svež. 67/I. 
podigao o svome trošku. Kanonik Barbić bio je u posjedu terena u Lukoranu na lokalitetu zvanom Starine ili Didine, s 13 gonjaja zemlje. S toga terena davao se Kaptolu dominikal $1 / 4$ vina i $1 / 3$ maslina.

Na lokalitetu zvanom Vrtlić (Vertlich) nalazio se zasađeni teren veličine jednog gonjaja s obvezom dominikala $u$ visini $1 / 3$ uroda. Kanonik Barbić posjedovao je dvije ograde, okružene suhozidom, u čijoj se sredini nalazio teren veličine oko pola gonjaja, ali nije bio dobar za sadnju, s obvezom dominikala od 1/3 uroda.

Na lokalitetu Bizza posjedovao je 3 gonjaja zemlje, s obvezom dominikala u visini 1/3 uroda. Blizu lokaliteta Dolac nalazio se vinograd veličine pola gonjaja u vlasništvu Antuna Dundovića koji je graničio s njegovim zemljištem i zemljištem monaha sv. Krševana, s maslinikom od 5 stopa i dominikalom od 1/3 uroda.

$\mathrm{Na}$ Lipičini je imao oko 2 gonjaja terena pod vinogradom i maslinikom, a sa sjevera se tu nalazio i teren veličine jednog gonjaja. Blizu Trokanjca nalazio se teren veličine oko 4 gonjaja, a blizu kuća nalazio se teren veličine 6 gonjaja. U blizini Zelenkova posjedovao je teren veličine 4 gonjaja dijelom šumovit, dijelom pod oranicom te ogradu veličine oko 12 gonjaja. Kanonik Barbić posjedovao je i pašnjak veličine oko 36 gonjaja na lokalitetu zvanom Babnjak i još jedan veličine 8 gonjaja prema jugu zvanom Draga Kona (Dragga Conna). ${ }^{69}$

Kaptolu je pripadala kuća koju je oporučno ostavio Lovro Lukša (casa Luxa) Mariner (mornar), ${ }^{70}$ s obvezom godišnjice za svoju i ženinu dušu. ${ }^{71}$ Kanonik Franko Franceschi oporučno je ostavio zadarskom Kaptolu 16. veljače 1738. godine kuću s obvezomjedne pjevane mise godišnje. ${ }^{72}$ Uzove, Kaptol je posjedovao još i kuće uz novi Kaštel (Castel Nuovo) i kuću uz kolonu kod crkve sv. Silvestra s pekarnom, ${ }^{73}$, kuću Mazzarelli, kuću Cortese uz crkvu sv. Četrdesetorice i kuću

69 Usp. HR-AZDN, f. 18, PKZ, Bonorum Beneficiorumque, fol. 73 - 75; Jakov Stipišić, Regesta pergamena iz zbirke obitelji Fanfogna Garagnin u muzeju grada Trogira (Dio drugi - Isprave XVI., XVII. i XVIII. stoljeća), Zb. Odsjeka povij. znan. Zavoda povij. druš. znan. HAZU, 21 (2003.), 287; Petar Runje donosi vijest da je svećenik Ivan Barbić kupio nekoliko gonjaja zemlje na Puntamici. P. Runje, Prema izvorima II., bilj. 61., 143.

70 ZKZD, sign. 16524, Ms. 453, fol. 14.

71 HR-AZDN, f. 18, PKZ, Liber Privilegiorum, fol. 173-174; HR-AZDN, f. 18, PKZ, Bonorum Beneficiorumque, fol. 358 - 361 .

72 HR-AZDN, f. 18, PKZ, Bonorum Beneficiorumque, fol. $684-685$.

73 Radi se o kući i nadarbini don Martina Budislavića smještenoj na granici s crkvom Gospe od Zdravlja u Zadru koju je zadarski Kaptol dodijelio don Antunu Filipiju kao jednostavnu nadarbinu zajedno s kućom i nadarbinom kanonika Mihovila de Biasija smještenoj u ulici crkve sv. Silvestra. Nadarbina Budislavić oporučno je ostavljena Kaptolu 23. rujna 1454. godine, a nadarbina de Biasija 12. lipnja 1472. godine. HR-DAZD, fond 31, Bilježnici Zadra (dalje: BZ), Donato Antonio Ferrari, 1774.-1796., b. I, svež 17, fol 2 r. 
uz crkvu sv. Ilije koju je Kaptol ustupio u najam zadarskim franjevcima i kuću Lighniceo. ${ }^{74} \mathrm{Uz}$ te, Kaptol je posjedovao jednu kuću smještenu in coriera ${ }^{75}$ koju je unajmilo zadarsko Sveučilišste. ${ }^{76}$

\section{KATASTARSKI UPIS DOBARA I PRIHODA ZADARSKOG KAPTOLA POČETKOM 19. STOLJEĆA}

Za usporedbu prikazanih dobara i potvrde autentičnosti nadarbina zadarskog Kaptola poslužit će dokumenti kanonske vizitacije arhiđakona i generalnog vikara Ivana Jurovića iz 1801. godine. U spisima kanonske vizitacije zadarskog Kaptola pohranjena je i katastarska knjižica pod naslovom Cattastro de Beni Fondi di proprietà del Venerabile Capitolo della Metropolitana di Zara. $^{77} \mathrm{U}$ njoj se donosi egzaktan opis kaptolskih zemljišta i nekretnina, trenutnih najmitelja početkom 19. stoljeća $s$ naznačenim prostornim veličinama, granicama, kućnim brojevima nekretnina u vlasnišstvu zadarskog Kaptola, brojem zasađenih vinovih loza i maslina te ukupnih obveza najmitelja prema Kaptolu i prihoda na godišnjoj razini. Površina zemljišta izražena je u zadarskim gonjajima i tavolama, iako se za kratkotrajne francuske uprave u Dalmaciji nastojalo uvesti metrički sustav mjera, koji ipak početkom 19. stoljeća nije zaživio. ${ }^{78}$ Jedan zadarski gonjaj nosi 342 tavole i 6 stopa. ${ }^{79}$ Prema katastarskoj knjižici kaptolska zemljišta pod naslovom Monte Ferrea prostorno su zauzimala kako slijedi:

- na području Smiljevca 11,5 gonjaja ili $27.174,5 \mathrm{~m}^{2}$;

- na području Monte Ferreo 10 gonjaja ili $23.630 \mathrm{~m}^{2}$;

74 Riječ je o dvojnoj kući kod crkve sv. Ilije koju je zadarskom Kaptolu oporučno ostavio arhiđakon Franjo Lighniceo. HR-AZDN, fond 16/5, Zadarska nadbiskupija/Metropolija (dalje: ZNM), Spisi, Nadarbine (beneficiji) - ovjerovljeni prijepisi dokumenata 15. st. i dalje.

75 Radi se o starom nazivu ulice Calle Carriera između današnjeg Narodnog trga i poljane Šime Budinića.

76 HR-AZDN, f. 18, PKZ, Liber Partium 32/V, fol. 2r.

77 HR-AZDN, f. 16/6, ZNM, Kanonske vizitacije, Vizitacija nadđakona i generalnog vikara I. Đurovića 1801.: Katastarski popis zemljišta u vlasništvu Zadarskoga kaptola.

78 O tome vidi rad: Marija Zaninović-Rumora, Mjere u Dalmaciji u vrijeme francuske uprave, Hrvati i Ilirske pokrajine (1809.-1813.) (ur. Franjo Šanjek), Zagreb, 2010., 499 - 508.

79 Od 16. stoljeća zadarski gonjaj ili gonjal iznosio je točno 2,363 $\mathrm{m}^{2}$. Marija ZANinović-RumorA, Stare mjere za površinu u sjevernoj Dalmaciji, Radovi Zavoda za povijesne znanosti HAZU u Zadru, (35) 1993., 127. Mletačka mjera tavola bila je manja mjera za površinu, a iznosila je $2.4483 \mathrm{~m}^{2}$. Stopa (piede) je mletačka mjera za dužinu, a iznosila je $0.347712 \mathrm{~m}$. Zlatko Herkov, Prinosi za upoznavanje naših starih mjera za dužinu i površinu - nastavak, Zbornik Odsjeka za povijesne znanosti Zavoda za povijesne i društvene znanosti HAZU, 8 (1977.), 149, 158. 
- na području Paprat 6 gonjaja i 300 tavola ili $15.950,25 \mathrm{~m}^{2}$;

- na području Pudarica 18 gonjaja i 108 tavola ili $43.321,6 \mathrm{~m}^{2}$;

- na području sv. Ivana 7 gonjaja, 256 tavola i 5 stopa ili $18.313,25 \mathrm{~m}^{2}$;

- na području sv. Marka 3/4 gonjaja ili 1.772,25 m²;

- na području Arco 10 gonjaja ili $23.630 \mathrm{~m}^{2}$ :

- na području Smokvica (Dračevac Zadarski) 7 gonjaja i 100 tavola ili $17.232 \mathrm{~m}^{2}$;

- na području Stubal (Dračevac Zadarski) 8,5 gonjaja i 200 tavola ili $21.465,5 \mathrm{~m}^{2}$

- na području Žankovac (Turanj) 18,5 gonja i 100 tavola ili 44.405,5 m².

Sveukupno je na tome području zadarski Kaptol posjedovao $236.894,85 \mathrm{~m}^{2}$ zemljišta na kojemu je bilo zasađeno 38.502 panja vinove loze, 138 maslina i manji broj stabala smokava. Dominikal na tim zemljištima iznosio je $1 / 4$ prinosa za žitarice i $1 / 5$ prinosa za mošt, a koncem 18. stoljeća ta su zemljišta dana u najam Ivanu Krstitelju Grilliju za godišnji iznos od 480 mletačkih lira. Na otoku Ugljanu, u mjestu Lukoran, Kaptol je posjedovao 79 gonjaja ili $186.677 \mathrm{~m}^{2}$, a na Pašmanu u Banju 8 gonjaja ili $18.904 \mathrm{~m}^{2}$.

Na području kapela Kaptol je posjedovao kako slijedi:

- pod kapelom sv. Marine 11 gonjaja i 100 tavola zemljišta ili $26.683 \mathrm{~m}^{2}$;

- pod kapelom sv. Klementa 4 gonjaja ili $9.452 \mathrm{~m}^{2}$;

- pod kapelom sv. Marka oko 7 gonjaja ili $16.541 \mathrm{~m}^{2}$;

- pod kapelom sv. Tome 3,5 gonjaja ili 8.270,5 $\mathrm{m}^{2}$;

- pod kapelom sv. Mihovila 5,5 gonjaja ili $12.996,5 \mathrm{~m}^{2}$;

- pod kapelom sv. Jurja 10 gonjaja i 86 tavola ili $24.223,4 \mathrm{~m}^{2}$;

- pod kapelom sv. Hipolita 23 gonjaja ili $54.349 \mathrm{~m}^{2}$.

Sveukupno je pod kapelama bilo $152.515,4 \mathrm{~m}^{2}$ zemljišta na kojima je bilo zasađeno 10.442 panja vinove loze i 146 stabala maslina. Na mjestu zvanom Crnošina (Cernoschina) u blizini Lukorana na otoku Ugljanu Kaptol je posjedovao 3 gonjaja zemlje ili $7.089 \mathrm{~m}^{2}$. Tereni pod kapelama također su dani u zakup Ivanu Krstitelju Grilliju za godišnji iznos od 480 mletačkih lira. Kaptol je posjedovao zemlje i pokraj kapele sv. Petra na Ižu, smještenom uz more, koje je početkom 19. stoljeća dao u najam obitelji Švorinić. ${ }^{80}$

Uz te, Kaptol je posjedovao i nadarbinu sv. Petra u Diklu, koju je kaptolskoj masi pripojio nadbiskup Vicko Zmajević, a potvrdio zadarski nadbiskup Mate

80 HR-AZDN, f. 16/6, ZNM, Kanonske vizitacije, Vizitacija nadđakona i generalnog vikara I. Đurovića 1801.: Katastarski popis zemljišta u vlasništvu Zadarskoga kaptola, br. 82. 


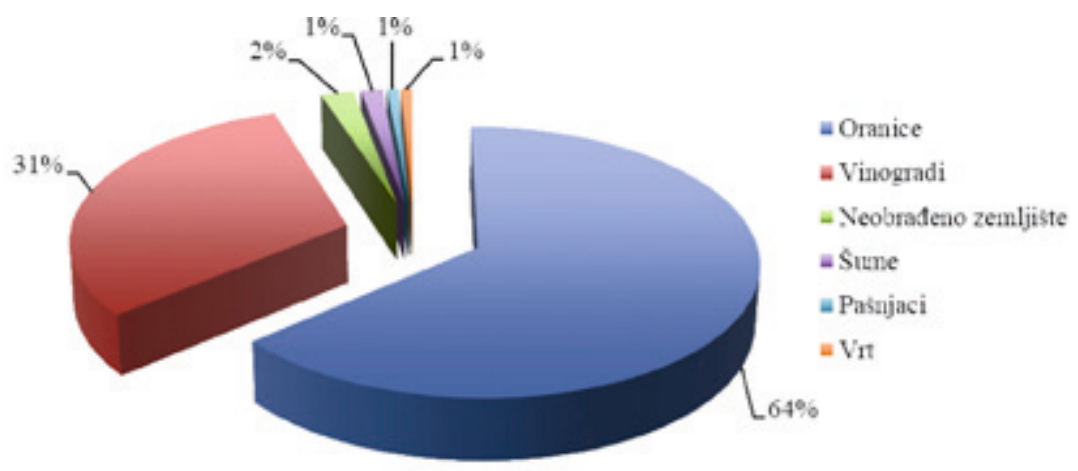

GRAFIKON 1. Vrste i udio zemljišnih čestica Zadarskog kaptola

Karaman 1746. godine, zbog siromašnog stanja Zadarskog kaptola ${ }^{81}$ Prihodi te nadarbine služili su za dnevnu distribuciju, vezanu uz korsku službu, svih nadarbenika Zadarskog kaptola u katedralnoj crkvi i kolegijalnoj crkvi sv. Šime. Posjedi su bili smješteni u crkvu sv. Petra u Diklu i na lokalitetu Zgon, prema Kožinu. Nadarbina sv. Petra prostorno je zauzimala 8 gonjaja i 100 tavola ili $20.775,5 \mathrm{~m}^{2}$ zemljišta, mahom oranica $\mathrm{s}$ neznatnim nasadima maslina. $\mathrm{Na}$ lokalitetu Zgon Kaptol je posjedovao 33.75 gonjaja i 200 tavola zemlje odnosno $81.131,25 \mathrm{~m}^{2}$ uglavnom pod oranicama, a manjim dijelom (4 gonjaja) pod vinogradima. U prilogu radu donose se imena kolona koji su početkom 19. stoljeća bili najamnici tih zemalja, zajedno s prostornom veličinom pojedinog zemljišta i njihovim granicama (Prilog 1).

Zadarski kaptol početkom 19. stoljeća raspolagao je s ukupno 138 zemljišnih, čestica od čega 88 oranica, 43 pod vinogradom, 3 nekultivirane čestice, 2 šume, 1 pašnjak i 1 vrt. Od ukupnog broja čestica 118 se nalazilo na kopnenom, a 21 na otočnom dijelu Zadarske nadbiskupije (Slika 1). Veći udio oranica ne treba čuditi s obzirom na to da je u to vrijeme proizvodnja žitarica bila na cijeni zbog nedostatka tih proizvoda na području Dalmacije, zbog sušnih i nerodnih godina još od druge polovice 18 . stoljeća ${ }^{82}$ te je početkom 19 . stoljeća pokrajina $u$ prosjeku dobivala žita za polugodišnju prehranu stanovništva. ${ }^{83}$

81 HR-AZDN, f. 18, PKZ, Bonorum Beneficiorumque, fol 713. Bula nadbiskupa Mate Karamana o pripajanju nadarbine sv. Petra u Diklu kaptolskoj masi pohranjena je u Arhivu Zadarske nadbiskupije. HR-AZDN, f. 18, PKZ, Razni spisi i rukopisi, kut. 8., br. 36.

82 Usp. Stijepо ОваD, Neke karakteristike stanja i kretanja na dalmatinskom selu od sredine 18. st. do Prvoga svjetskog rata, Dalmacija u novijoj hrvatskoj povijesti i kulturi (ur. Ante Bralić), Zadar, 2014., 17.

83 Š. PERIČIĆ, Gospodarske prilike Dalmacije, 35. 


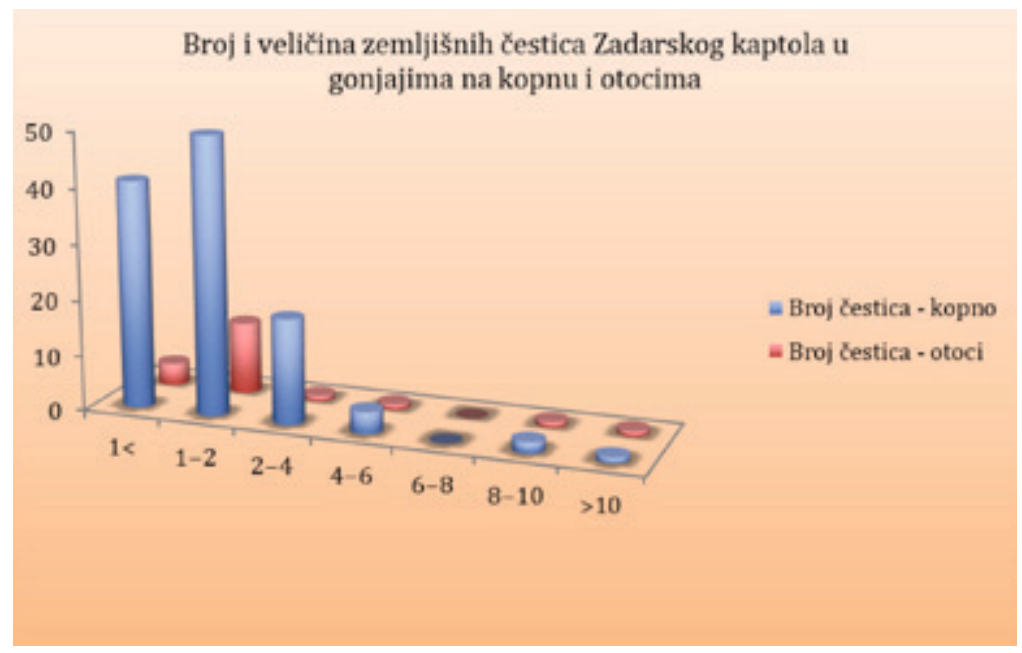

GRAFIKON 2. Broj zemljišnih čestica (vertikalna os) Zadarskog kaptola na kopnu i otocima prema njihovoj prostornoj veličini izraženoj u gonjajima (horizontalna os).

Uz to, zemljišne su čestice bile rascjepkane i uglavnom male površine (Slika 2), što korespondira i sa stanjem posjeda drugih crkvenih institucija u Zadru, ali i Dalmaciji općenito. ${ }^{84}$ Takva konstelacija zemljišta uzrokovala je prvenstveno poteškoću pri sklapanju zakupa i najamnih ugovora, a u bitnome je utjecala na visinu najamnine, ali i razinu prinosa zasijanih kultura. Zamjetno je da je početkom 19. stoljeća dominikal s tih zemljišta iznosio redovito $1 / 4$ podavanja za žitarice $s$ oranica i $1 / 5$ podavanja mošta iz vinograda, prema uvjetima kolonata na staroj stečevini. Može se iz svega zaključiti da su najveći teret toga sustava podnosili dalmatinski težaci - koloni, što je bitno utjecalo na kvalitetu njihova svakodnevnog života početkom 19. stoljeća, što je nerijetko dovodilo do razmirica između vlasnika posjeda i kolona, a štetilo je i napretku zemljoradnje u Dalmaciji. ${ }^{85}$

Uz zemljišta Kaptol je raspolagao i nekretninama koje također početkom 19. stoljeća davao u najam. Kaptol je posjedovao 31 nekretninu u gradu od kojih je na godišnjoj razini ubirao 627 mletačkih lira i 15 soldi. ${ }^{86}$ Kaptol je ulagao i novčana

84 Usp. I. Ostojıć, Metropolitanski kaptol u Splitu, 40 - 42; Lovorka Čoralić, Zemljišni posjedi dominikanskog samostana u Zadru u XVII. i XVIII. stoljeću, Croatica Christiana periodica, 18 (1994.) 33, $217-218$.

85 Usp. Š. PERIČIĆ, Gospodarske prilike u Dalmaciji, 17 - 18.

86 HR-AZDN, f. 16/6, ZNM, Kanonske vizitacije, Vizitacija nadđakona i generalnog vikara I. Đurovića 1801.: Katastarski popis zemljišta u vlasništvu Zadarskoga kaptola, Descrizione de beni fondi di città..., br. 62-78. 
sredstva u Monte di Pietà i pomoć nekim obiteljima u gradu, uz godišnju kamatu, od čega je bio predviđen prihod od 1615 mletačkih lira i 15 soldi na godišnjoj razini. Međutim, kako je navedeno u katastarskom popisu, godinama Kaptol nije uspijevao podići kamate iz Monte di Pietà te je bio vjerovnik za 1.276,85 franaka. Od tih prihoda Kaptol je namirivao milostinju za 14 pjevanih i 140 tihih misa godišnje, od ukupno 737 misa koje je u ime ostavštine i ostalih obveza godišnje slavio u zadarskoj katedrali. ${ }^{87}$

\section{ZAKLJUČAK}

Zahvaljujući izvješću zadarskog arhiđakona Ivana Jurovića početkom 19. stoljeća precizno se može utvrditi ekonomsko stanje Zadarskog kaptola uoči preustroja dalmatinskih biskupija za vrijeme druge austrijske uprave. Razvidno je da su dobra Prvostolnog kaptola sv. Stošije u Zadru, stjecana stoljećima raznim oporučnim ostavštinama i darovnicama vladara, građana i crkvenih službenika, velikim dijelom sačuvana u njegovu posjedu do početka 19. stoljeća. Unatoč kratkoročnim reformatorskim nastojanjima u vrijeme prve austrijske uprave, a napose u vrijeme francuske uprave u Dalmaciji, Zadarski je kaptol u 19. stoljeće ušao sa starim posjedovnim odnosima kolonatskog sustava, ali s umanjenom količinom prihoda, čemu su, među ostalim nepovoljnim povijesnim (ne) prilikama, pridonijele relativno česte promjene vlasti i njihov bitno drugačiji pogled na crkvene institucije i njihovu ulogu u društvu.

Precizni popisi kaptolskih posjeda, njihov geografski smještaj na području Zadarske nadbiskupije, način njihova ustupanja kolonima i najamnicima te kvalitativni opisi zemljišta doprinose boljem razumijevanju ekonomskog stanja Zadarske crkve početkom 19. stoljeća te su ujedno svjedočanstvo o siromaštvu i nepovoljnim životnim uvjetima dalmatinskog težaka u razmatranom razdoblju.

87 HR-AZDN f. 16/6, ZNM, Kanonske vizitacije, Vizitacija nadđakona i generalnog vikara I. Đurovića 1801.: Katastarski popis zemljišta u vlasništvu Zadarskoga kaptola, Descrizione de Censi... br. 79-89. 


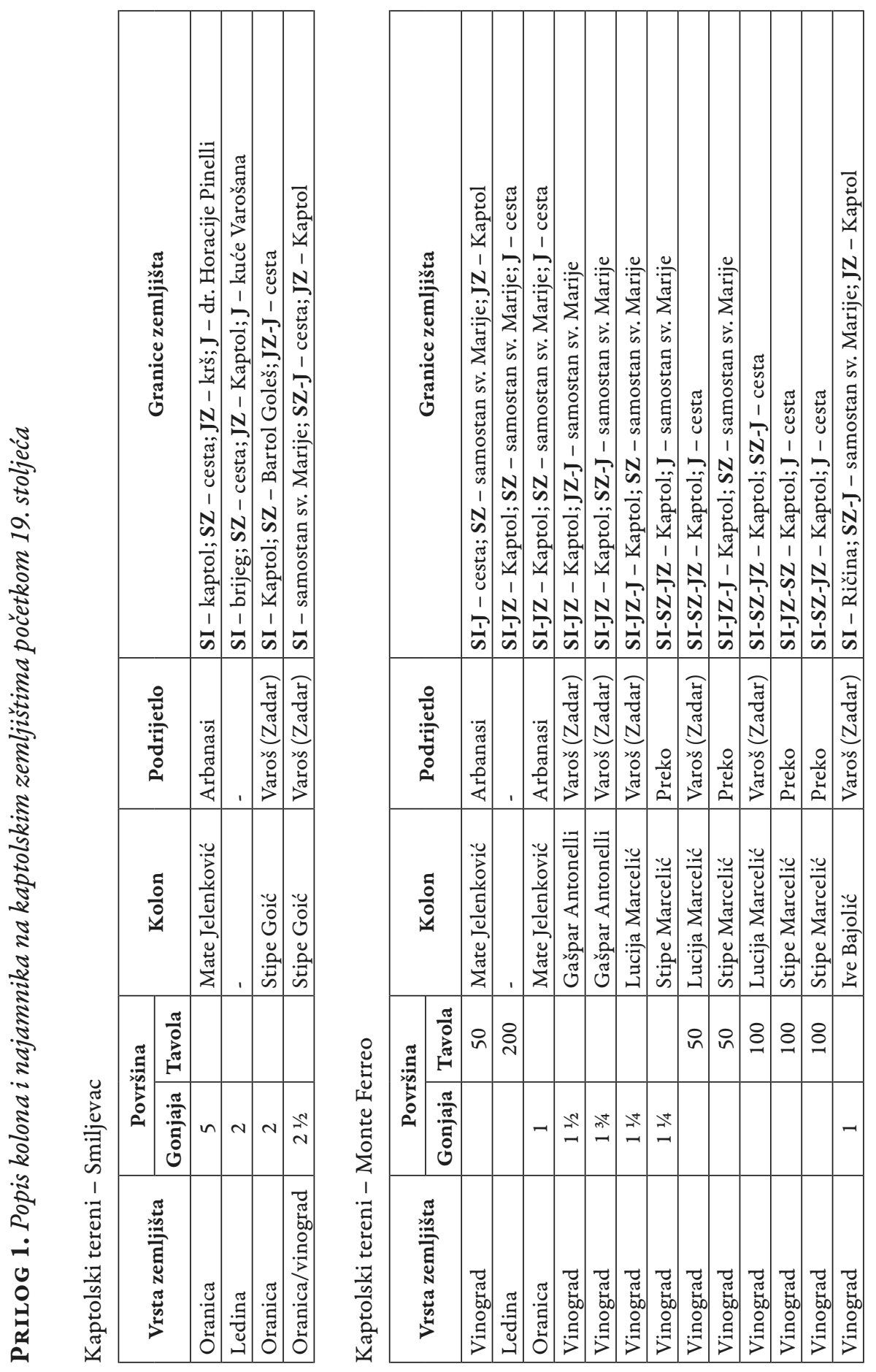




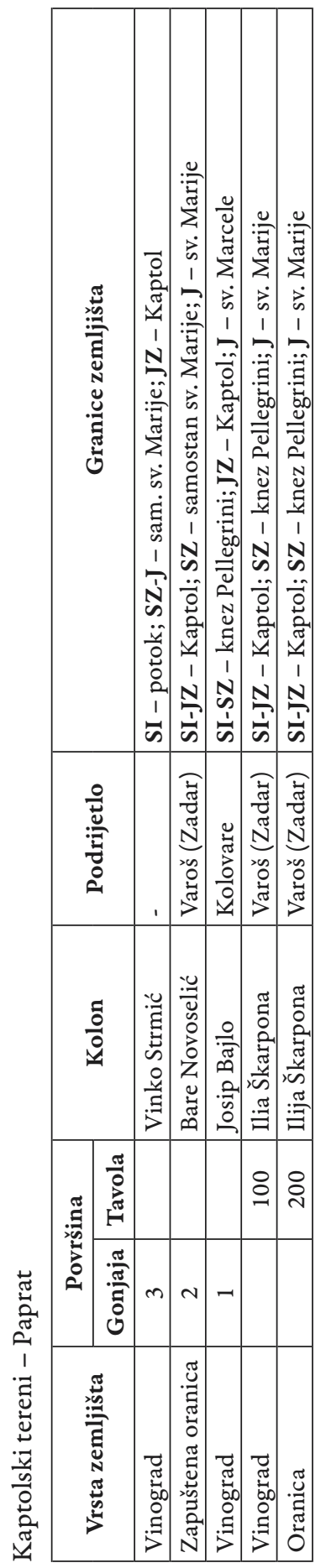

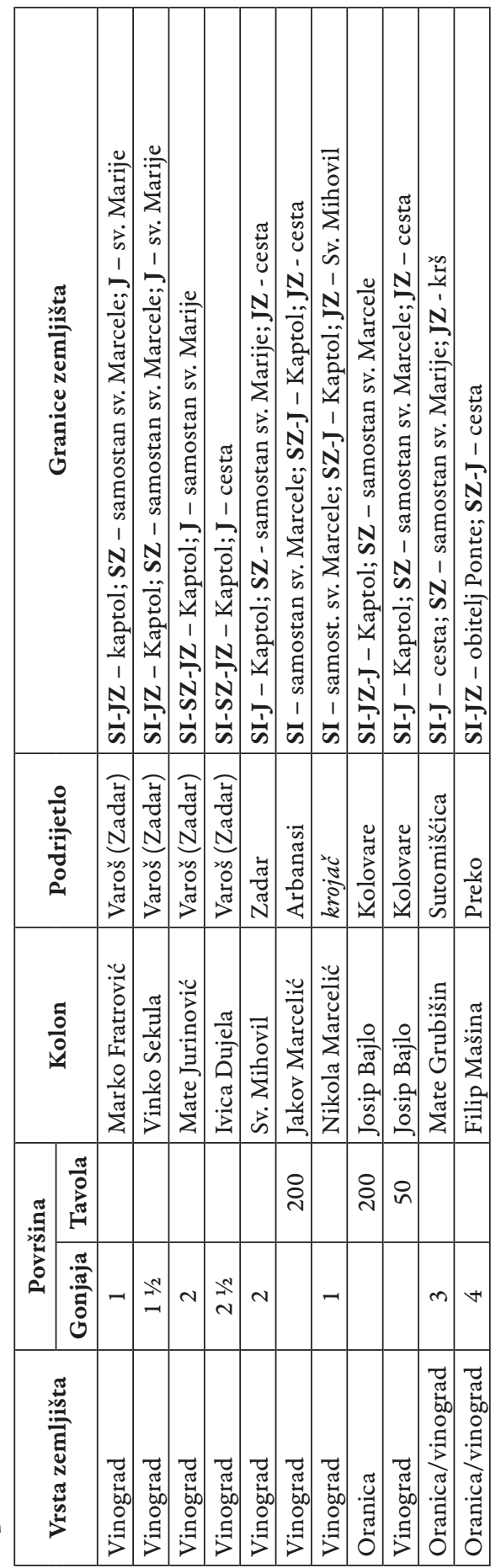



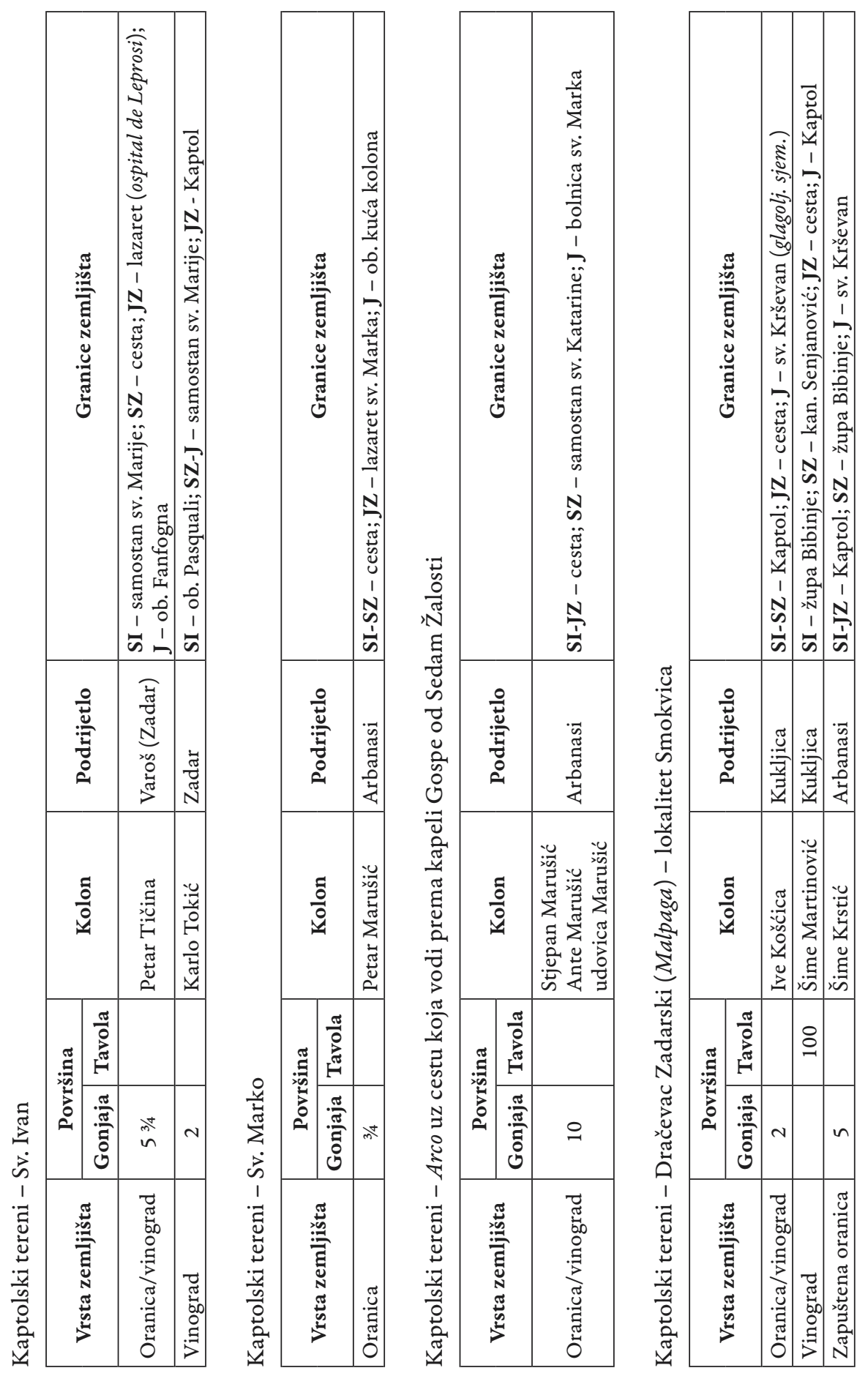


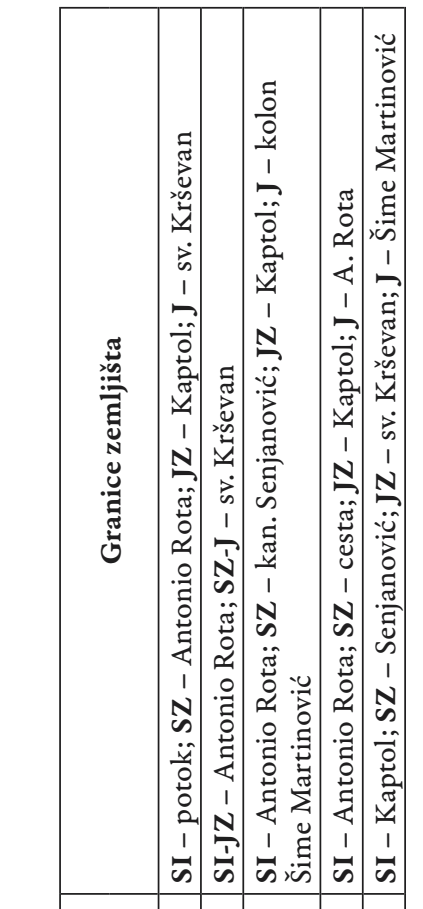

|

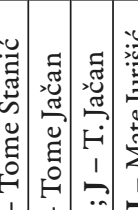

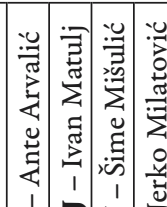

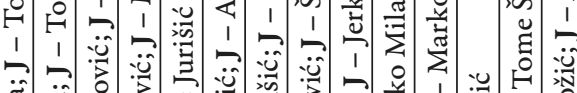

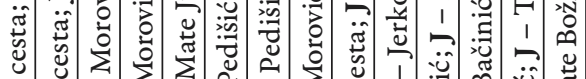

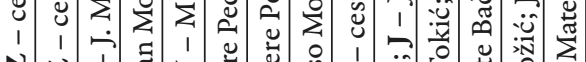

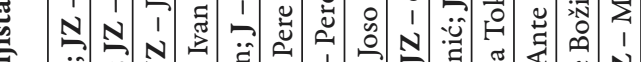

:

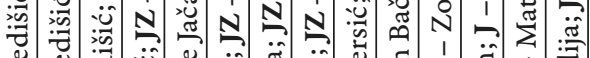

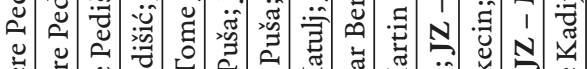

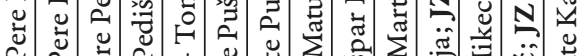

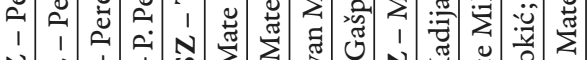

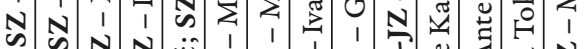

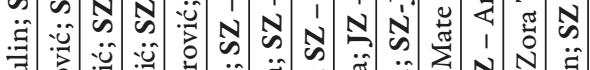

可

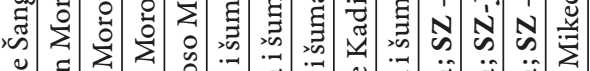

范

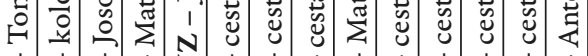

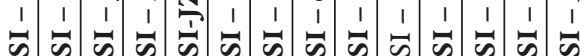

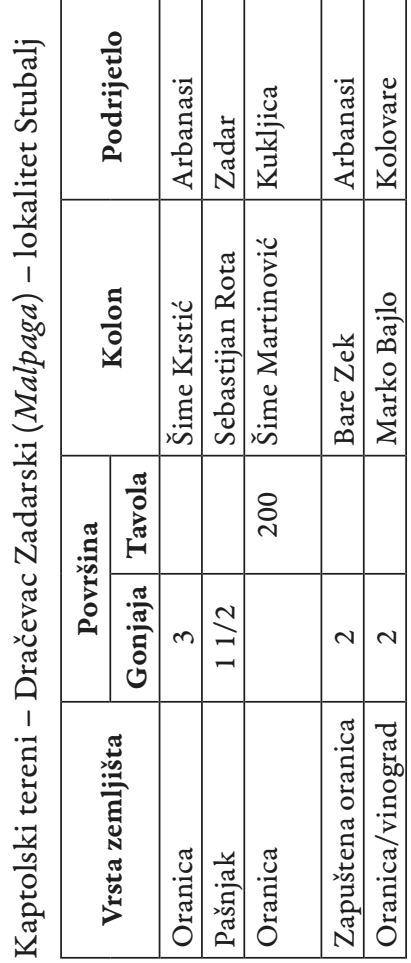

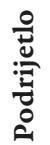

胥

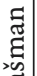

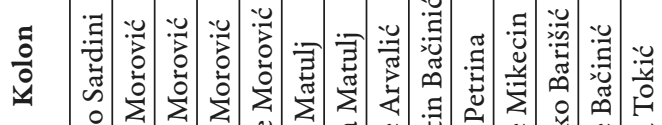

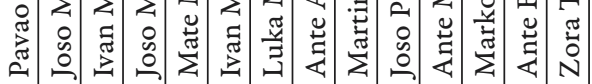

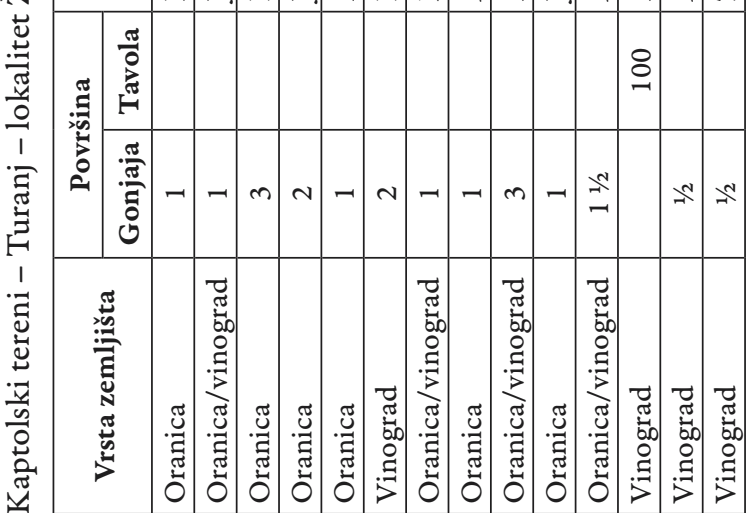



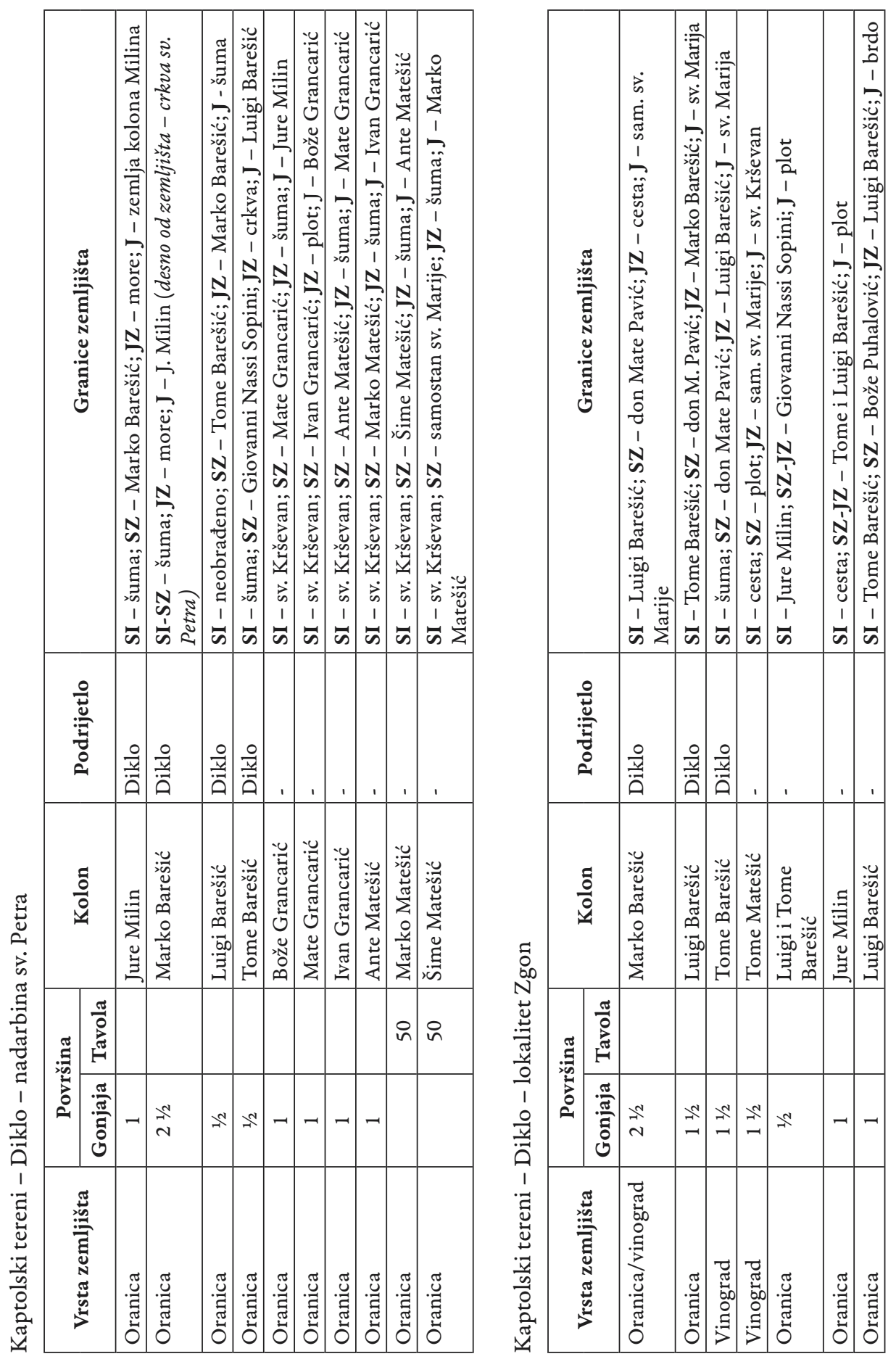

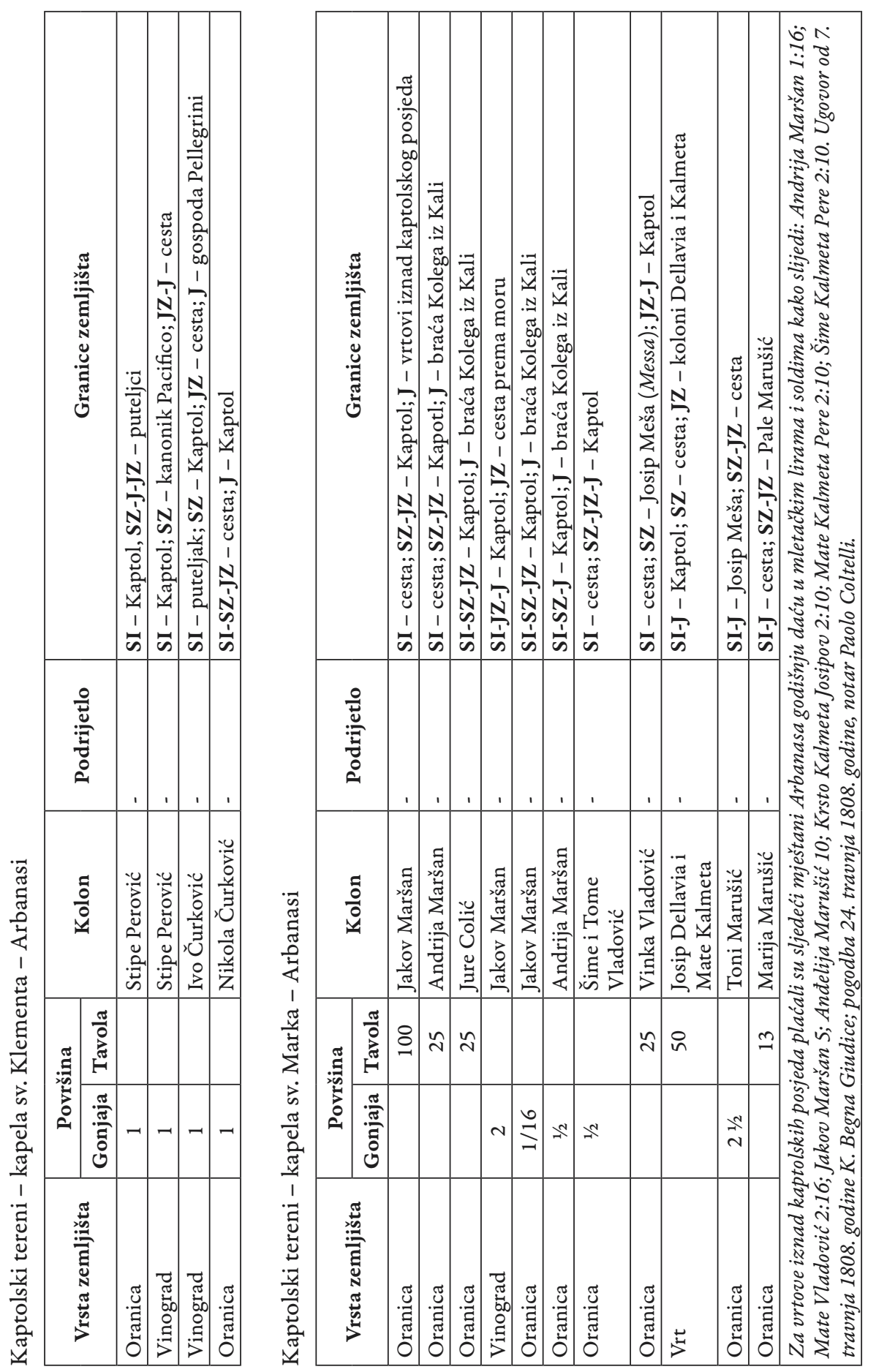


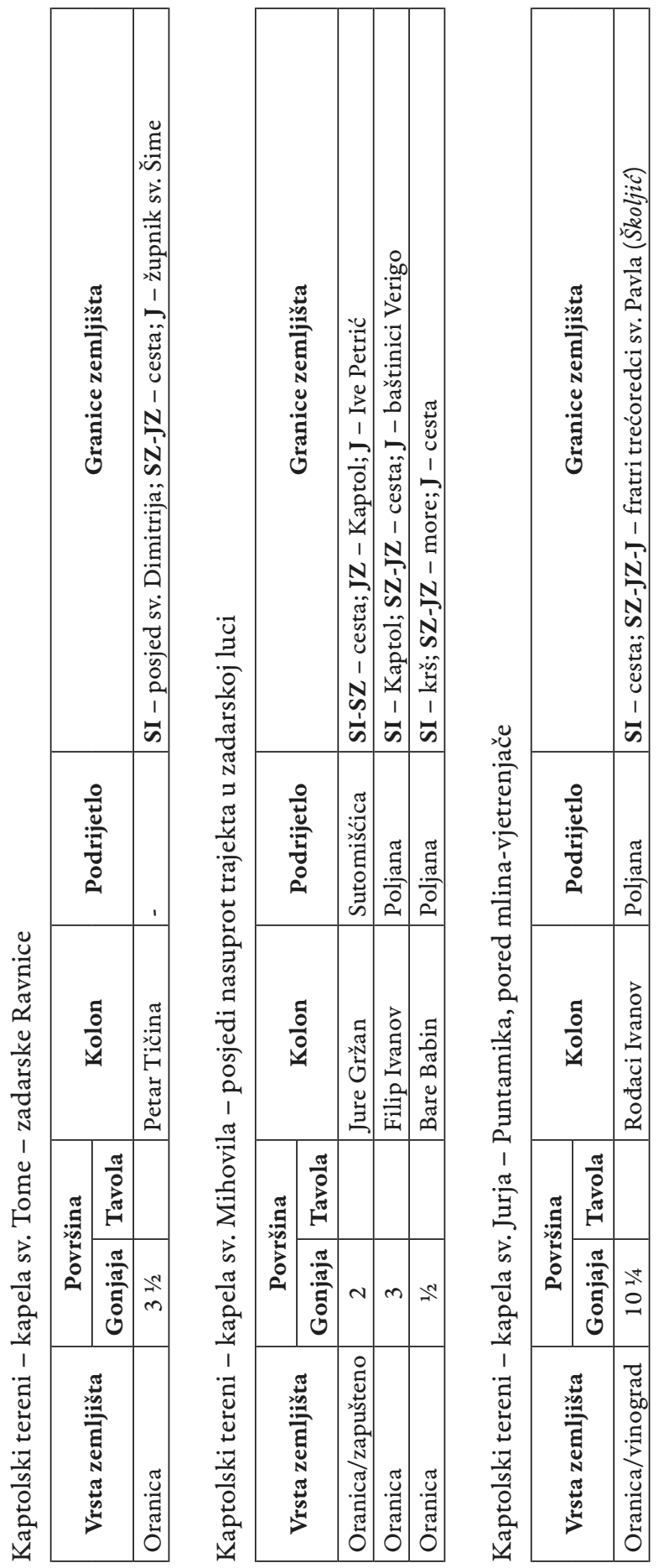



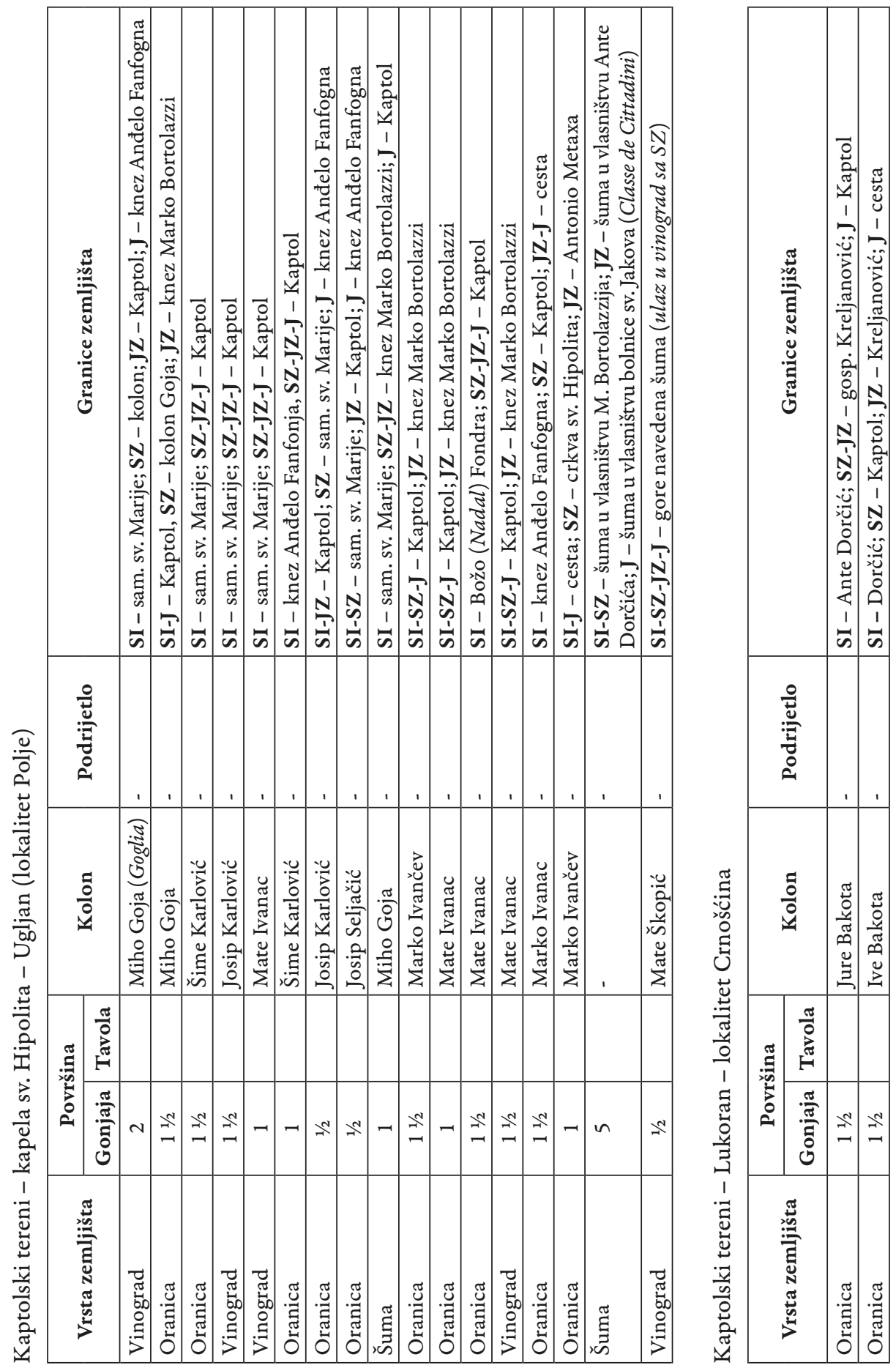


\section{Zdenko DUNDOVIĆ}

\section{THE ECONOMIC SITUATION OF THE ZADAR CAPITOL ON THE EVE OF RECONSTRUCTING DALMATIAN DIOCESES IN THE EARLY 19TH CENTURY}

\section{SUMMARY}

Based on of the reports of the Zadar capitular vicar Ivan Jurović and the unpublished archival material of the Archives of the Archdiocese of Zadar, the paper presents the property of the Capitol of the Cathedral of St Anastasia in Zadar in the early 19th century. Data on the Zadar Capitol property was correlated with the property and revenues of the Zadar clergy on the islands, coastline and hinterland. This correlation contributed to learning more about the economic status of the clergy in the early 19th century when the reorganization of the church administration in Dalmatia occurred. Also, contributions to the work help to better understand the location of the Capitol land estates and the difficulties encountered by church institutions concerning the colonate system in renting land during the reorganization of church administration in Dalmatia, which took place during the Second Austrian Administration in Dalmatia (1813-1918). They also contribute to the understanding of the general economic situation of the Church in the Zadar area. We can also trace the way, conditions and the rent rate of church land to Dalmatian farm labourers in Zadar. All this partly explains the difficult economic circumstances in which landowners and tillers of the old system found themselves in at the beginning of the19th century. The former had difficulties due to the commitments made by the land owner and the latter, due to severe working conditions, low yields on relatively small agricultural areas and often high amounts of giving to landlords.

Keywords: Capitol of Zadar, 19th century, church economy, church property. 